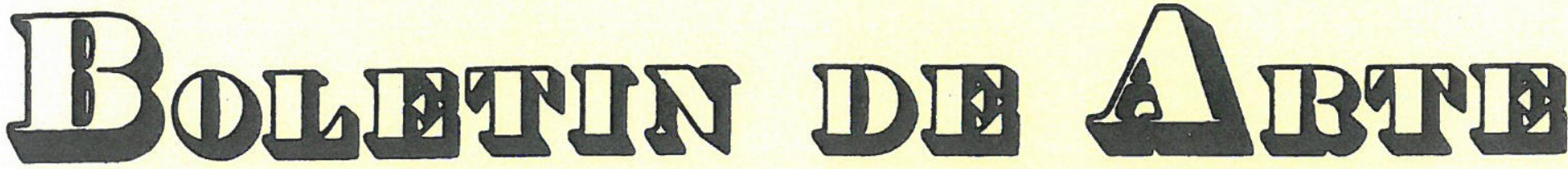

Núm. 20

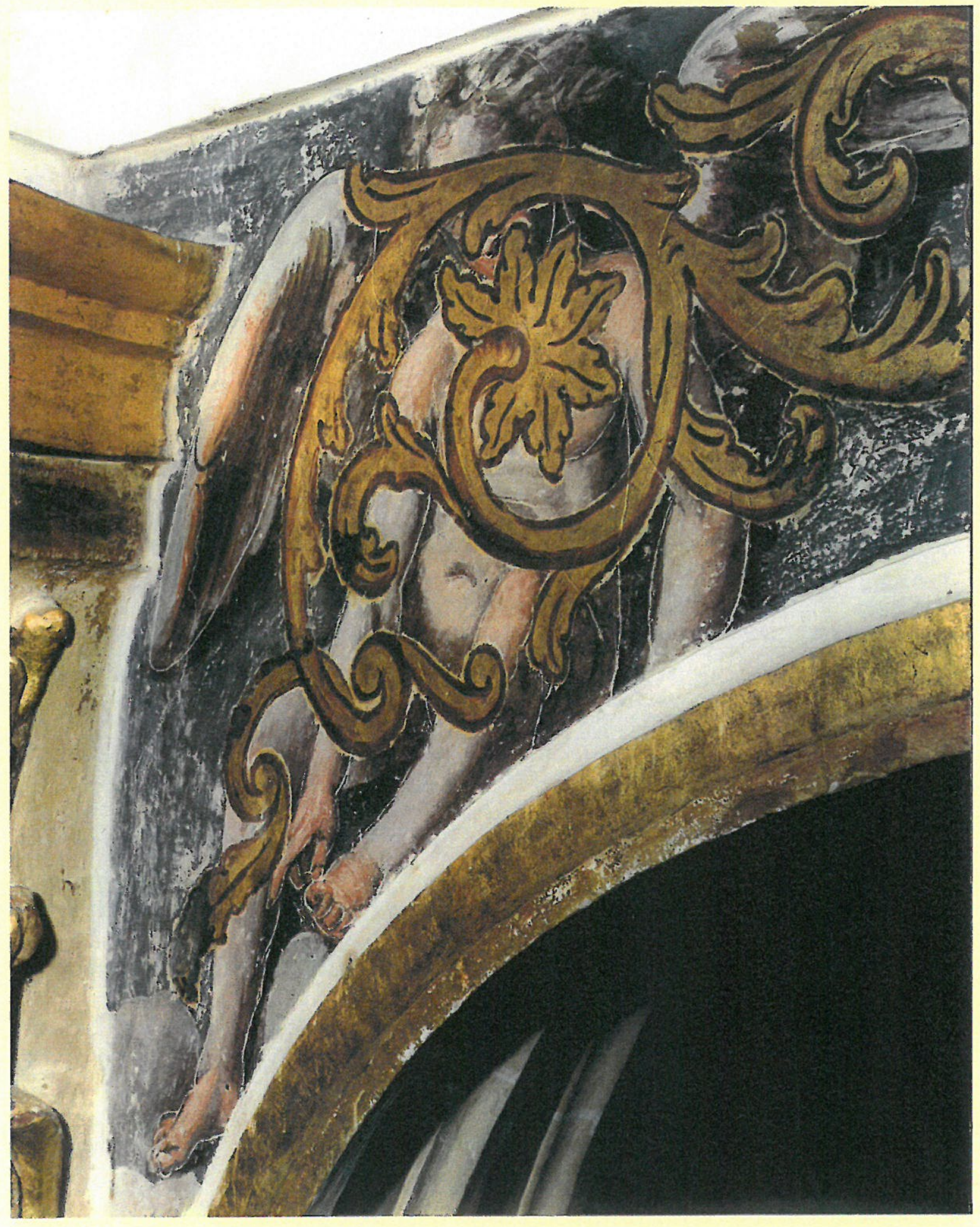

UNIVERSIDAD DE MALAGA

DEPARTAMENTO DE HISTORIA DEL ARTE 
EL COLEGIO DE LA ASUNCIÓN Y AMALIA HEREDIA LIVERMORE: HISTORIA DE DOS VIDAS PARALELAS, por Eva Ma Ramos Frendo .. INTRODUCCIÓN DE LA ICONOGRAFÍA WAGNERIANA EN LA BARCELONA DE LA RESTAURACIÓN (1882-1885), por Lourdes Jiménez Fernández

APROXIMACIÓN A LA INDUSTRIA DEL PAN EN MÁLAGA Y SU EVOLUCIÓN TECNOLÓGICA: DE LOS MOLINOS DE SAN TELMO AL PROCESO INDUSTRIAL, por Francisco José Rodríguez Marín .......... UN ARTE NACIONALISTA ESPAÑOL: REGIONALISMO VERSUS "NOUCENTISME". AÑOS 20, por Eliseo Trenc Ballester.

DE PROSTITUTAS Y OTRAS VÍCTIMAS. LA PINTURA SOCIAL DE ANTONIO FILLOL (1870-1930), por Victoria E. Bonet Solves

MITO Y FOLCLORE: LA IMAGEN DE LA MUJER EN UNA DÉCADA DE CARTELES DE SEMANA SANTA (1921-1931), por Francisca Torres Aguilar.

ARTE Y PLATAFORMA CULTURAL EN MÁLAGA DURANTE EL SIGLO XX. 1900-1975, por Teresa Sauret Guerrero

GUTIÉRREZ SOTO EN MARBELLA: LOS FUNDAMENTOS DEL PLACER, por Francisco Javier Moreno Fernández

EL FALSO ESPEJO DE LA MUJER. LA IMAGEN PUBLICITARIA HOY, por Natalia Tielve García

EL DEBATE SOBRE LA CRISIS DEL ARTE CONTEMPORÁNEO A FINALES DE SIGLO, por María Teresa Méndez Baiges

UN PROYECTO DE ESTUDIO EN LA HISTORIA DEL ARTE: PRESENTACIÓN Y DESCRIPCIÓN DE UN MODELO DE TESAURO PICTÓRICO-ARTÍSTICO (I), por Nuria Rodríguez Ortega

LA CAPILLA MAYOR DE LA CATEDRAL DE MÁLAGA, PALIMPSESTO Y ESCENOGRAFÍA PINTADA por Juan Antonio Sánchez López y Estrella Arcos von Haartman

PATRIMONIO PICTÓRICO DE ANTEQUERA. EL CLAUSTRO DEL CONVENTO DE LA MAGDALENA, por Rosario Camacho Martínez ..... EL COLOR EN LA ARQUITECTURA AGRÍCOLA MALAGUEÑA, por Juan $\mathrm{M}^{\mathrm{a}}$ Montijano García

LA MEMORIA OLVIDADA. APROXIMACIÓN AL PATRIMONIO PICTÓRICO MURAL DE RONDA: SIGLO XVIII, por Eduardo Asenjo Rubio 


\title{
LA CAPILLA MAYOR DE LA CATEDRAL DE MÁLAGA: PALIMPSESTO Y ESCENOGRAFÍA PINTADA.
}

\author{
Juan Antonio Sánchez López \\ Estrella Arcos von Haartman
}

\begin{abstract}
La reciente intervención conservadora y restauradora llevada a cabo, con el patrocinio de Winterthur, sobre el conjunto de elementos ornamentales de la Capilla Mayor de la Catedral de Málaga constituye el punto de partida para una exhaustiva revisión historiográfica y documental de la que constituye, sin lugar a dudas, la gran empresa artística de la Málaga del Renacimiento. El descubrimiento de un importante conjunto de pinturas murales debidas al pintor italiano Cesare Arbassia y sus colaboradores (ocultas en el XVIII con motivo de la nueva configuración plástica del Altar) y las implicaciones derivadas del acontecimiento demuestran cómo Historia del Arte y Conservación pueden y deben caminar juntas, abriendo otras pautas metodológicas y enfoques críticos más flexibles para el análisis y comprensión plural de los productos culturales
\end{abstract}

Cuando varias disciplinas comparten un estudio en torno a las manifestaciones culturales suele imponerse una razón primordial, fundamentada en el incremento cualitativo y cuantitativo experimentado por el potencial investigador ocupado en convertirlas en objetivo prioritario y simultáneo de los respectivos campos de conocimiento. Esa mayor amplitud de ópticas y procesos convergentes proporciona capacidad para enfrentarse a las obras de arte como "originales irrepetibles", exigiendo la eficaz combinación de metodología científica sobre una dilatada base humanística. Si entre los objetivos pretendidos por la Historia del Arte se encuentra el de profundizar en el conocimiento de los modelos culturales precedentes a través de las fuentes materiales y la información contextual, es absolutamente necesario apoyar esta actuación en una labor de conservación que facilitará la tarea del especialista a la hora de analizar, cuantificar, documentar e interpretar los datos del pasado $^{1}$. La intervención directa sobre el soporte material de la obra de arte ofrece conclusiones más complejas, por cuanto las técnicas de ejecución, los materiales empleados y el "historial" de la pieza (su naturaleza, génesis y cronología que normalmente salen a la luz en la intervención directa) completan el bagaje de

${ }^{1}$ Este trabajo se integra en el Proyecto de Investigación n ${ }^{\circ}$ PB95-0477 "La arquitectura pintada en Málaga y Melilla. Siglos XVI-XX", financiado por la DGICYT. 


\section{Juan Antonio Sánchez López / Estrella Arcos von Haartman}

conocimientos teóricos integrados en la investigación histórico-artística. Del mismo modo, esta última es imprescindible antes de abordar cualquier actuación sobre el bien cultural, pues la conservación debe fundamentarse en una clara definición del mismo y de su relación con el entorno.

En el caso de la Capilla Mayor de la Catedral de Málaga se hace evidente cómo cada programa de conservación, más allá de los objetivos de tratamiento, supone por sí solo y genera al mismo tiempo una coyuntura única e irrepetible para documentar, investigar y estudiar la estructura de la obra de arte, la cual se encuentra indisolublemente unida al instante de la intervención, hasta el punto de que, una vez transcurrido el mismo, las condiciones iniciales pierden aquel grado óptimo dificultando las posibilidades de verificación brindadas por la observación directa.

\section{LA CUESTIÓN DEL PALIMPSESTO (Juan Antonio Sánchez)}

Aunque a costa de tanto repetirlo pueda parecer ya un tópico, la imagen de una Catedral, entendida ésta como proyecto arquitectónico y problema constructivo, utopía frente a realidad en otras palabras, permanece estrechamente ligada a la ciudad reflejando sus deseos y limitaciones, sus delirios y frustraciones, sus pretensiones y carencias. Tan estrecha simbiosis ha impreso a estos edificios una marcada cualidad "orgánica", directa responsable de un comportamiento que, a lo largo de los siglos, la ha hecho asemejarse y asimilarse a un auténtico ser vivo. Ciertamente, no fueron pocas las ocasiones en las que la Catedral ha demostrado su proclividad a metamorfosearse, a transformarse en pos de asumir, no sin que la situación resultase forzada en frecuentes ocasiones, cuantas adaptaciones, alteraciones y reformas iban demandando las necesidades litúrgicas, las concepciones espaciales y, por supuesto, la evolución de ese pensamiento colectivo que determina nuevas intervenciones al compás marcado por la sucesión y/o colisión de diferentes criterios, gustos, tendencias y modas ${ }^{2}$.

Ese avanzar sobre el sedimento de lo anterior y que hace pervivir la idea de la destrucción como génesis de la creación nos hace descubrir en las Catedrales españolas auténticos palimpsestos. En su caracteriología, las significaciones emblemáticas no afectan solamente a los elementos decorativos, sino que se revelan en la estructura general de un edificio configurado mediante la yuxtaposición y/o superposición de módulos y/o estratos significativos de cada uno de los períodos que

\footnotetext{
2 Véanse sobre el particular los trabajos de GARCÍA MELERO, J.E.: "Realizaciones arquitectónicas de la segunda mitad del siglo XVIII en los interiores de las catedrales góticas españolas”, en Espacio, Tiempo y Forma, Serie VII-2, 1989, págs. 223-286 y "Espiritualidad y estética: las transformaciones en los exteriores de las catedrales góticas españolas en el siglo XVIII", en Hispania Sacra n 141, 1989, págs. 603-640. En esta misma línea se sitúa el artículo de RIVERA, J.: "Metamorfosis de las Catedrales españolas", en Ars Sacra, nºs. 4-5, 1997-1998, págs. 32-36.
} 
La capilla mayor de la Catedral de Málaga: palimpsesto y escenografía pintada

jalonan la "vida" del inmueble desde su "nacimiento" a su madurez; reflexión esta última que insta a considerarlo un proyecto "abierto" en toda ley, de no darse una planificación exhaustiva y cerrada desde el principio. En este sentido, y desde el marco de la referida investigación interdisciplinar, la intervención conservadora acometida durante 1998 en la Capilla Mayor de la Catedral de Málaga ha permitido confirmar los supuestos anteriores en el ámbito concreto de un espacio sagrado concebido como auténtico corazón del magno edificio renacentista ${ }^{3}$. De tal forma, que el descubrimiento de las pinturas murales del XVI trasciende con creces la simple constatación "arqueológica" de un estrato anterior al habitualmente conocido. Ha supuesto también un acercamiento de primera mano a los problemas de la técnica de ejecución del fresco, así como a la incidencia del contexto histórico sobre la fisonomía de este tipo de conjuntos arquitectónicos, sin olvidar la oportuna revisión historiográfico-documental que camina, en sintonía con otros trabajos, hacia una inminente revalorización crítica del principal artista implicado en el proceso, el pintor italiano Cesare Arbassia (1547-1607). No obstante, para captar en su plenitud las implicaciones aludidas es absolutamente preciso referirnos a la historia desde el principio.

\section{El Altar del XVI}

En 1549 se iniciaba una fase decisiva en la construcción de la Catedral de Málaga. Solventadas las trabas e indecisiones que frenaron el proyecto renacentista desde que éste comenzara su andadura a partir de 1525, Diego de Vergara "el Viejo"(1499-1583) conseguía avanzar la obra hasta tal punto que, a su muerte en 1583, se hallaban construidas las capillas de la girola, parte de los brazos del crucero y, por supuesto, la Capilla Mayor, cuyas gradas, altar y solería culminaría su hijo Diego de Vergara Echaburu $(+1597)^{4}$. Con relativa antelación al óbito del maestro Vergara debió concluirse la estructura arquitectónica del santuario, generándose una esbelta unidad espacial de planta semidecagonal marcada por pilares cruciformes con columnas corintias adosadas, sobre las cuales apean altos y estrechos arcos de medio punto, reforzados en su parte inferior con diafragmas. El empleo del dado brunelleschiano rematado por pilares de ático contribuye a definir en realidad un doble alzado, articulado en sendos niveles superpuestos separados entre sí por el cinturón de la cornisa.

\footnotetext{
${ }^{3}$ AA.VV.: Retrato de la Gloria. Restauración del Altar Mayor de la Catedral de Málaga, Barcelona, Winterthur, 1999.

${ }^{4}$ PÉREZ DEL CAMPO, L.: "Versatilidad y eclecticismo. Diego de Vergara (h. 1499-1583) y la arquitectura malagueña del siglo XVI", en Boletín de Arte, 7, 1986, págs. 81-100.
} 


\section{Juan Antonio Sánchez López / Estrella Arcos von Haartman}

Culminada en su configuración esencial la Capilla Mayor, hacia 1575- 1580 es posible detectar ciertos movimientos en torno al programa iconográfico y decorativo que adopta como soporte sus muros y elementos tectónicos. De hecho, casi a la par que se elevaba la Fábrica y bajo la supervisión del Maestro Mayor, debieron ejecutarse las estatuas de cuerpo entero de los ocho jóvenes mártires (Ciriaco, Paula, Lorenzo, Sebastián, Esteban, Catalina de Alejandría, Inés y Eufemia) ubicadas al frente de los pilares superiores, los otros tantos bustos de ancestros de Cristo (Abraham e Isaac, Moisés, David y Juan el Bautista) y Padres de la Iglesia (Agustín de Hipona, Ambrosio de Milán, Gregorio Magno y Jerónimo) dispuestos en el friso, además de distintos pormenores escultóricos como los atlantes, niños, serafines y las risueñas cabezas de querubín que aparecen en las claves o bien aplicados a las repisas y doseletes avenerados que cobijan las imágenes martiriales. El silencio documental que, de momento, rodea la autoría de estas piezas no impide reconocer en ellas, al menos, cuatro manos diferentes encargadas de plasmar los modelos impuestos por Diego de Vergara, similares a los bustos de la iglesia de Nava del Rey así como los esculpidos en las enjutas de la Catedral de Salamanca cuando el mencionado arquitecto trabajaba en ella ${ }^{5}$. Ese presumible reparto de las labores de imaginería entre artistas locales o afincados en Málaga constituye el factor responsable de los diferentes tratamientos. Con todo, y pese a sus carencias plásticas, las esculturas salvaguardan en todo instante su eficacia comunicativa haciendo gala de los atributos, rótulos y filacterias que los hacen identificables con absoluta nitidez por parte del espectador, contribuyendo así al esclarecimiento y lectura del programa.

Tanto en el Quinientos como en la siguiente centuria, las principales intervenciones acometidas en el recinto de la Capilla Mayor responden al interés y la preocupación personal de los sucesivos prelados, quienes no dudaron, a veces con extraordinario entusiasmo, en entregarse a la promoción y mecenazgo de cuanto fuera necesario para acondicionar el santuario con la dignidad requerida en tales situaciones. Hacia 1580, durante el pontificado de Francisco Pacheco y Córdoba, se prestó un nuevo impulso a las tareas decorativas en lo tocante a la policromía, pintura y dorado de la arquitectura y aditamentos escultóricos. Para conseguir su objetivo, el prelado reclutará los servicios del pintor italiano Cesare Arbassia, natural de Saluzzo y amigo personal del pintor y humanista cordobés Pablo de Céspedes al que conoció en Roma y con quien colaboró en el programa pictórico de la Iglesia de Trinitá dei Monti ${ }^{6}$. Céspedes,

\footnotetext{
5 CAMACHO MARTÍNEZ, R.: "De mezquita a templo cristiano: etapas en la transformación y construcción de la Catedral de Málaga”, en AA.VV., Retrato de la Gloria, pág. 27

${ }^{6}$ Sobre Cesare Arbassia véase GABRIELLI, N.: "Studi sul pittore Cesare Arbassia", en Atti della Societá Piemontese di Archeología e Belle Arti, a. XV, 1933, págs. 316-335; LLORDÉN SIMÓN, A.: Pintores y doradores malagueños. Ensayo histórico-documental (Siglos XV-XIX), Ávila, Real Monasterio de El Escorial, 1959, págs. 51-76; SÁNCHEZ CANTÓN, F.J.: "El obispo Pazos, el cronista Morales y el pintor César Arbasia", en Archivo Español de Arte y Arqueología, XIII, 1937, págs. 73-74; BRESSY, M.: "Cesare Arbassia pittore saluzzese del 500 (1547-1607)", en L'Arte, 1961, págs. 51-55 y CLAVIJO GARCÍA, A.: "Un pintor manierista en Málaga: el italiano César Arbasia", en Actas del I Congreso de Historia de Andalucía. Andalucía Moderna, siglos XVI-XVII, vol. 1, Córdoba, 1978, págs. 307-320.
} 
cuya personalidad atrae hacia sí el liderazgo y la dependencia ideológica del debate teórico del momento, aparece como el más directo inspirador de la llegada de Arbassia, en 1577, a tierras españolas, donde desarrollará una interesante actividad al servicio de las Catedrales de Córdoba y Málaga y del linaje de los Bazán en su palacio de El Viso del Marqués, en Ciudad Real. No dejan de resultar sugerentes las ventajosas y decisivas consecuencias que los contactos eclesiásticos, aristocráticos y culturales cordobeses depararon al artista italiano. Su influencia permitiría a Arbassia infiltrarse con facilidad en aquellos ambientes sociales que constituían la base de la comitencia ${ }^{7}$. Toda vez que su presencia discontinua en Málaga, entre 1579-1589 y vertebrada por las dos secuencias comprendidas por su trabajo en la Capilla Mayor, responde a la iniciativa personal y a las empresas artísticas acometidas en la primera Iglesia de la Diócesis durante los pontificados de sendos prelados oriundos de la antigua capital califal: el ya mencionado Francisco Pacheco y Córdoba (1575-1587) y su controvertido y polémico sucesor en la Mitra, Luis García de Haro $(1587-1597)^{8}$.

Es posible que la elección de Arbassia para la ornamentación pictórica de la Capilla Mayor viniese condicionada por las tareas que el artista italiano desempeñó, en torno a 1579 al servicio de Pacheco dentro del ambicioso y suntuoso programa (reemplazado en el XVIII) ideado por el obispo para la Capilla de la Encarnación en el que resultaría implicado, asimismo, el escultor Juan Bautista Vázquez ${ }^{9}$. Lo cierto es que Cesare Arbassia se hallaba embarcado de pleno en la pintura de la Capilla Mayor a mediados de 1582, pues a finales del mes de mayo de dicho año se suscriben tres protocolos notariales que indican la suspensión temporal de la obra, con motivo de un viaje del pintor a Italia, presumiblemente para contraer matrimonio. En esta primera fase, la actividad debió centrarse en el dorado de estructuras arquitectónicas y paños ornamentales, según confiesa el mismo artista al declarar:

Sepan quantos esta carta vieren cómo yo César Arbassia natural de la ciudad de Saluzao que es en las partes de Ytalia en la provincia del Piamonte, maestro del arte de pintor, estante al presente en esta noble e muy leal ciudad de Málaga digo que, por cuanto por mandado del Illmo. y Rmo. señor Francisco Pacheco de Córdoba, obispo de Málaga, yo he pintado y dorado ciertas obras en la Yglessia mayor nueba de esta ciudad, en especial tengo dorado y pintado la bóbeda

\footnotetext{
${ }^{7}$ Sobre el tema véase RUBIO LAPAZ, J.: Pablo de Céspedes y su círculo. Humanismo y Contrarreforma en la cultura andaluza del Renacimiento al Barroco, Granada, Universidad, 1993.

${ }^{8}$ SÁNCHEZ LÓPEZ, J.A.: "Sueño del Renacimiento y despertar de la Contrarreforma (1540-1597)", en AA.VV.: El esplendor de la Memoria: el Arte de la Iglesia de Málaga, Málaga, Junta de Andalucía, 1998, págs. 32-40.

${ }^{9}$ MEDINA CONDE, C.: Descripción de la Santa Iglesia Catedral de Málaga, desde el 1487 de su erección, hasta el presente de 1785, Málaga, Imprenta del Correo de Andalucía, 1878, págs. 44-45.
} 


\section{Juan Antonio Sánchez López / Estrella Arcos von Haartman}

de la capilla mayor y los ecdos. y pilares, que llega la dicha obra hasta la cornyza grande y tengo dorada la dicha cornyza y frisso menos ciertas figuras y faxas, e queda y rresta por dorar y pintar desde la dicha corniza hasta el suelo de la dicha capilla mayor, y tinyendo la dicha obra en este estado se me a ofresido aver de yr forsosamente a la dicha ciudad de Salusso y su señoría me aze iso merced de darme lic ${ }^{a}$ para que baya e pueda ir a la dha. ciudad de Saluzao con que me obligue que dentro de un año primero y siguiente bolberé a esta dicha ciudad a acabar y feneser de todo punto la dicha obra que así tengo comenssada de qual tiempo su $s^{a}$ me aguarda para no meter otro oficial que la acabe hasta passado el dicho año, por tanto, por el tenor de la presente carta prometo y me obligo que, syendo nuestro Señor serbido de darme bida y saludd, dentro de un año primero ziguiente que corre y se a de contar desde el día de San Johan de junio primero que bendrá deste presente año bolber a esta ciudad, y no ofresiéndoseme algúm ympedymento justo y con el fabor e ayuda de nuestra Señora acabaré y feneseré la dicha obra según e como la dexo comensada, donde no, que passado el dicho año su señoría pueda dar la dicha obra a otra qualquiera oficial e persona que a su sra. pareciere para que la fenezca y acabe syn aguardarme más tiempo del dicho año, y no binyendo dentro dél, como dicho es, su señoría quede libre de la $\mathrm{mrd}$. que me haze y palabra que me a dado de aguardarme... ${ }^{10}$

Bastante más escrupuloso se revela el licenciado Diego Fernández Romero, mayordomo de la Fábrica Mayor, a la hora de registrar documentalmente, el mismo día, las condiciones económicas y el estado exacto de la decoración pictórica en los momentos previos a la partida de Arbassia. En su empeño de reflejar con rigurosa exhaustividad en la escritura los avatares del proyecto, el delegado episcopal alega:

... digo que por quanto César Arbassia maestro del arte de pintor, rresidente en esta ciudad, por mandado del Illmo. y Rmo. señor don Francisco Pacheco de Córdoba, obispo de Málaga, a hecho ciertas obras en la dicha Santa Yglessia de esta dicha ciudad, de pintura, entre las quales doró y pintó la capilla, rrexas y rretablo del señor don fray Bernardo Manrrique, de buena memoria, obispo que fue de este obispado, por la cual se le dieron y pagaron tres myl ducados, que tiene rrecividos y está pagado dellos, y asimismo pintó la bóbeda de

${ }^{10} \mathrm{~A}($ rchivo) $\mathrm{H}($ istórico) $\mathrm{P}($ rovincial) de M(álaga), Escribanía de Alonso de Valencia, leg. 592 (1582-
$1583)$, s/f. 
La capilla mayor de la Catedral de Málaga: palimpsesto y escenografía pintada

la capilla mayor e los arcos e pilares della hasta la corniza grande e la dicha corniza e friso lo dexa dorado menos la figura del rrey David y sobre ella dos faxas que sobre las demás ban doradas y la figura de Santo Agustín y dos filetes sobre el que sobre las demás van doradas y un pedaÇo de moldura de papo de paloma de la moldura grande que será como una tercia y otro pedaÇo de papo de paloma más pequeño, que será como dos varas, y la figura de San Yerónimo y una de las faxas que corre sobre ella y los dos rincones de los traspilares de los dos pilares donde acaba la media capilla, por todo lo qual, que así tiene fffo.(...) en la dicha capilla mayor, su señoría mandó dar tres myll e quinientos ducados e de ellos a rezibido el dicho César Arbassia dos myll e seissientos e treinta y ocho ducados y se le rrestan y quedan debiendo ochocientos y sesenta y dos ducados a cumplimiento de los dichos tres mil e quinientos ducados ... ${ }^{11}$

El advenimiento de Luis García de Haro a la silla episcopal de Málaga, en 1587, deparó al Cabildo la desagradable sorpresa de contemplar la interrupción de las obras, preludio de la decepcionante experiencia de verse obligado a asistir, al año siguiente, a la consagración de una Catedral inconclusa. El obispo asumió bajo su directa responsabilidad la urgente necesidad de habilitar el espacio de la Capilla Mayor poniendo dineros de su casa y la asistencia de su persona con vistas a la ya inminente apertura al culto del templo ${ }^{12}$. Acatando sus precisas instrucciones, Cesare Arbassia procedía al dorado del arco toral del crucero, pedestales de columnas y pilares, jaspeado de arcos y, quizás, la pintura de los frescos de la Pasión. El pintor también afrontaba en esta segunda fase al frente de la decoración de la Capilla Mayor un ciclo de diecisiete tablas para el Tabernáculo central, rematado en 1588, cuyo diseño tiende a atribuirse al pintor italiano ${ }^{13}$. En esta tesitura, el licenciado Diego Fernández Romero asumía, de nuevo, la representación episcopal a la hora de ajustar con Arbassia el correspondiente pliego de condiciones, suscrito el 13 de Febrero, estipulándose en el mismo la obligación de este último de dorar por 800 ducados de oro bruñido todas las molduras, fajas, filetes y los demás miembros más altos con el techado y los campos se estofarán de colores azules y otras colores y algunas sierpes fingidas, dándolo y levantándoles con sus sombras en sus lugares a donde el artíffice con su discreción mejor convenga, en un plazo de seis meses durante los cuales se acometerían de modo simultáneo otras labores ornamentales. Singular importancia reviste el, por desgracia desaparecido, programa pictórico del ciborio

\footnotetext{
11 Ibídem.

12 A(rchivo )C(atedral) de M(álaga), leg. 1027, pza. 2, Actas Capitulares, lib. 13 (1579-1588), fols. 397r.397v., Cabildo de 2-Agosto-1588.

13 A.H.P.M., Escribanía de Bernardino de Escobar, leg. 526 (1588-1589), s/f.
} 


\section{Juan Antonio Sánchez López / Estrella Arcos von Haartman}

cuya estructura turriforme facilitaba la distribución de las tablas por el frente del monumento, el anverso y reverso de las puertas del manifestador y el tambor de la cúpula. Seguramente por directa inspiración del prelado, el memorial anexo a la escritura de obligación se hace eco con escrupulosa minuciosidad de la temática de las historias y enigmas representados en los cuadros de Arbassia, así como de los motes latinos que conferían un cierto matiz emblemático y jeroglífico, respectivamente, a tales asuntos. En última instancia, prevalecería en ellos el empleo de un lenguaje mixto imbricado en el contexto cultural de la época y fundamentado en la fusión/asociación de la palabra y la imagen, en cuanto dominios próximos e interrelacionados que obligan al espectador a desplegar lo que el texto sobredetermina respecto a la figura y, a su vez, lo que ésta condensa en relación a la palabra ${ }^{14}$. De ahí que no resulte sorprendente la capacidad amplificadora que las citas bíblicas asimiladas a motes operan sobre el trasfondo connotativo de las imágenes, renovando su significado y haciéndolas receptoras de sugerentes matices cuya relativa complejidad cabría entender como fruto de esa atinada simbiosis entre leer y mirar ${ }^{15}$ :

Hay en el primer cuerpo tres cuadros debajo del pórtico y en ellos ha de haber pintadas tres historias, cada paño la suya. En la primera Elías con un ángel que baja del cielo dándole pan con una letra que diga: IN FORTITVDINE HVIVS CIBI. En el cuadro de medio ha de ir pintado la historia del Maná con la letra: PANEM ANGELORVM. En el tercero la historia de Daniel y la letra: TIMENTIBVS SE ... ... ... En los dos quadros de los dos lados ha de haber, en cada uno, enigma en la una ha de haber figurado un globo del mundo, pintado en él un mappa sobre el cual estará pintado un altar con el Santíssimo Sacramento y un poco más alto estará la figura de JesuXto. nro. Redentor que parezca que rompe y sube a los cielos con su resplandor $y$ en los cielos irán figurados sus planetas y en lo más alto, cielo empíreo, estará la divinidad de Dios Padre con el Espíritu Sancto, queriendo significar que cuando Dios nuestro Señor subió a los cielos, no por eso nos desamparó, dejándonos el Santíssimo Sacramento; ha

\footnotetext{
${ }^{14}$ RODRÍGUEZ DE LA FLOR, F.: Emblemas. Lecturas de la imagen simbólica, Madrid, Alianza Editorial, 1995, pág. 170 y BARTHES, R.: Lo obvio y lo obtuso, Barcelona, Paidós, 1987, pág. 23. Para una aplicación particular véase GARRONI, E.: Proyecto de Semiótica. Mensajes artísticos y lenguajes no verbales. Problemas teóricos y aplicados, Barcelona, Gustavo Gili, 1975, pág. 360. Este último autor es taxativo al afirmar que la dimensión verbal no es extraña a la imagen, pero es interna respecto a ella, como una de las condiciones de su estructura y de su legibilidad.

${ }^{15}$ La relación semántica e icónico-textual entre los motes y pinturas del Tabernáculo de 1588 la establecimos con profundidad en SÁNCHEZ LÓPEZ, J.A.: "Non Vos Delerinquam. La Catedral de Málaga y un sueño del Renacimiento", en Espacio, Tiempo y Forma, Serie VII-6, 1993, págs. 221-240 e Historia de una utopía estética: el proyecto de Tabernáculo para la Catedral de Málaga, Málaga, Universidad, 1995, págs. 41-52.
} 
de haber su letra que diga: NON VOS DELERINQVAM. En la otra parte estará pintada el Arca del Testamento Viejo con la letra que diga: MISTERIVM FIDEI. En las dos puertas ha de haber cuatro figuras en cada una media puerta la suya, en las dos medias puertas de la delantera estará pintado San Pablo señalando al Stmo. Sacramento con la letra: HOC ENIM ACCEPI A DOMINO . En la otra San Juan Bautista y letra que diga: ECCE QVI TOLLIT PECCATA MVNDI. En las otras dos medias puertas del reverso ha de haber otras dos figuras, Melchisedech y (...) ofreciendo pan y vino ...... En los nichos se pintarán los apóstoles que cupieren... ${ }^{16}$

Los trabajos de restauración-conservación practicados a los frescos y pinturas murales de la Capilla Mayor por el equipo de la profesora Estrella Arcos han permitido calibrar la envergadura de las tareas realizadas por Cesare Arbassia y sus colaboradores. Y, de paso, calibrar en su justa medida el protagonismo del obispo García de Haro como más que presunto mentor de las líneas programáticas que venían a culminar, con brillantez y sin redundancias, las propuestas iconográficas anteriores. Qué duda cabe que la obsesiva intención del prelado de concluir la Capilla Mayor en el menor tiempo posible le obligaría a tomar personalmente las riendas del proceso decorativo, para lo cual resultaba imprescindible imponer una rígida planificación que, por supuesto, también pasaría por definir, sin ambages y hasta el más mínimo detalle, los temas que pretendía representar dejando al pintor la libertad para interpretarlos acorde a las pautas de su propio estilo. A tenor del entusiasmo con que el Licenciado Gaspar de Tovar describe poéticamente el recinto, hacia 1603, la impresión causada por la Capilla Mayor tras la consagración de la basílica debía ser rotundamente radiante, pues desde la Tierra al Cielo/ son un racimo de oro./ Pilares, Tabernáculo y figuras/ (que alumbra todo el suelo) ${ }^{17}$.

Cuando Cesare Arbassia da por finalizada sus tareas, la estructura arquitectónica de la Capilla Mayor de la Catedral de Málaga distingue en su alzado, desde el arranque de los pilares hasta la bóveda del crucero, siete zonas diferenciadas topográfica, estilística e, incluso, materialmente por cuanto el predominio de las superficies enfrescadas por el pintor en el primer nivel contrastan con la iconografía escultórica de los estratos superiores. El cinturón de la cornisa verifica la transición entre ambos registros al haberse apostado por compensar el lance entre sendas artes plásticas confiriéndoles un protagonismo compartido en esta zona. La situación

\footnotetext{
${ }^{16}$ A.H.P.M., Escribanía de Bernardino de Escobar, leg. 526 (1588-1589), s/f. El tema iconográfico correspondiente al mote NON VOS DELERINQVAM no es otro que el de la Invitación Eucarística de la Trinidad.

17 TOVAR, G. de: Pintura y breve recopilación de la obra de la Santa Iglesia Mayor de Málaga, Antequera, Imprenta de Claudio Bolán, 1603. Inserto en MEDINA CONDE, C. de: op. cit., pág. 68.
} 
también permite advertir la responsabilidad mucho mayor detentada por Arbassia en esta segunda etapa respecto a la ejercida en el momento de su incorporación a la obra, cuando su misión parecía ceñirse más bien a remarcar las líneas maestras de la fábrica valiéndose del complemento del oro y la policromía. Por contra, su retorno a la seo malacitana bajo García de Haro le permitirá afrontar la resolución de composiciones narrativas de cierta aparatosidad y, sobre todo, revelar parte de sus dotes como escenógrafo al idear una serie de soluciones decorativas que recuerdan a los motivos empleados habitualmente en sus trabajos profanos en España e Italia $^{18}$.

Las siete zonas establecen una jerarquía de contenidos cuyo vértice continua siendo el ciborium o tabernáculo, por cuanto la Capilla Mayor de la Catedral de Málaga, paradigma del santuario renacentista, asumía desde el principio una inequívoca vocación de capilla sacramental, asimilada metafóricamente al quasimítico Templo de Jerusalén y configurada en su concepto a imagen y semejanza de un maravilloso palacio místico habitado por Cristo, Rex Gloriose Martyrum, Sol Verus, Sol Iustitiae, Sol Salutis ${ }^{19}$. En virtud de esta filosofía, la presencia del templete, la nueva Arca de la Alianza, se entiende como el hito desde el cual se verifica la Shekinah o Teofanía eucarística que irradia a los diferentes estratos del alzado custodiada por los serafines y querubines esculpidos, mientras es contemplada por la Iglesia Sufriente constituida por los oficiantes y asistentes al culto y las Iglesias Triunfante y Militante, representadas por las estatuas de los jóvenes mártires que dieron su vida por y a imitación de Cristo, los bustos de los ancestros y profetas que hablaron de su Pasión y Resurrección y los de los Padres de la Iglesia que interpretaron la Nueva Ley. Por su parte, las bóvedas del Altar y su inmediata del crucero incorporan los relieves alegóricos de la Fe y la Caridad. Ambas permanecen supeditadas a la representación de la Virgen y el Arcángel San Gabriel recordando al espectador la Encarnación y venida de Cristo, cuya condición de hombre mortal y verdadero trae al mundo la única Esperanza al permitir el cumplimiento de las profecías sobre la Redención. A los pies de estos relieves, las corpulentas esculturas de ángeles que hieren calaveras valiéndose de la Cruz como arma refrendan, con el apoyo efectista de la imagen macabra, la trascendencia mesiánica del programa e inciden en el protagonismo de Cristo como Sacerdote y Víctima

\footnotetext{
${ }^{18}$ Sobre este apasionante tema véanse los trabajos de BLÁZQUEZ MATEOS, E.: "Los Escenarios pintados de Cesare Arbassia: Paisajes idilicos y de Soledades", en Bollettino della Societá per gli Studi Storici, Archeologici e Artistici della provincia di Cuneo n 109, 1993, págs. 57-64; "Escenografías paisajísticas del palacio del Viso del Marqués. Las imágenes móviles del gran salón”, en Revista de Historia NavalInstituto de Historia y Cultura Naval, 1997, págs. 59-68; "La morada filosófica y el programa mitológicotemporal de la casa del pintor Cesare Arbassia en Saluzzo. El autorretrato como síntesis y emblemas de los géneros", en Boletín del Museo e Instituto Camón Aznar n 74, 1998 , págs. 85-100 y "El mito de las Hespérides y las alegorías mitológicas en el Humanismo hispano. El ciclo pictórico-literario para el jardín pintado del Marqués de Santa Cruz", en Ibídem n 73, 1998, págs. 9-33.

${ }^{19}$ SÁNCHEZ LÓPEZ, J.A.: "Rex Martyrum, Sol Salutis. El Palacio Cristológico", en AA.VV., Retrato de la Gloria, págs. 35-54.
} 
propiciatoria que obtuvo la inmortalidad para sí mismo y sus seguidores, una vez culminada su lucha contra el Mal.

Como puede observarse, García de Haro asumía la terminación de la Capilla Mayor con la mayor parte de sus líneas programáticas perfectamente ajustadas en torno a la apoteosis del Triunfo eucarístico. Sólo bastaba precisar y culminar lo ya realizado, lo cual justifica que se mostrase especialmente selectivo a la hora de encomendar a Cesare Arbassia las zonas bajas de la Capilla que aún restaban por decorar. La Catedral renacentista quedaba así convertida en escenografía parlante del ideario contrarreformista que proclama la unidad de toda la Iglesia en torno a Cristo, reivindicando la legitimidad del credo católico y la eficacia del martirio como argumentos de cariz proselitista y combativo. Ya en un terreno meramente formal, el criterio de Cesare Arbassia (y, desde luego, de sus mentores) se decanta hacia una concepción literalmente escenográfica de la arquitectura, dentro de la cual el alzado no viene sino a proporcionar el "andamiaje"o vehículo vertebrador de la tramoya a la que se adhieren los elementos discursivos integrantes del plan iconográfico. Con ello, se ofusca la identidad del vocabulario constructivo como elemento real y poseedor de valores estéticos singulares. De ahí que el recurso al despliegue crisocromático y esculto-pictórico (sin dejar nunca de adaptarse con "docilidad" a la fábrica que le sirve de asiento) aparezca, pese a todo, como una fórmula para incrementar y reforzar las cualidades estéticas de una arquitectura sutilmente cuestionada en su sobria desnudez y a la que en esta tesitura se considera indispensable "vivificar" mediante semejantes tratamientos plásticos.

Según referimos antes, el trabajo de Cesare Arbassia comprende dos tipos de decoraciones murales: ornamentales e historiadas. Su espacio vital abarca los entrantes del friso, las enjutas de los arcos y los paramentos planos de los diafragmas. En el friso, una serie de paños desarrollan un abigarrado diseño de formas vegetales enroscadas en el que predomina el efecto de masa y la explosión colorista, quizás pretendiendo rivalizar con los compactos volúmenes y la policromía de los ocho bustos colaterales. Turgentes roleos y floraciones infladas de savia adoptan un tortuoso trazado de complicados ritmos curvos, replegándose en torno al robusto penacho de carnosas hojas de acanto dispuesto en la parte central. Frente a la estilización predominante en el candelieri renacentista, el flagrante naturalismo del repertorio fitomorfo empleado por Arbassia parece presagiar soluciones de la centuria posterior, ya plenamente sintonizadas con la opulencia y la exuberancia barrocas. Las suaves entonaciones rosáceas, anaranjadas, verdes y azuladas brillantemente contrastadas contra fondo azul agrisado subrayan la apuntada densidad de los motivos. No obstante, el exceso de fogosidad actúa en detrimento de la percepción del diseño, por cuanto dificulta la nítida apreciación del detalle que sería deseable, sobre todo teniendo en cuenta el ángulo de visión trazado desde el suelo por el espectador. En este punto podríamos plantearnos el siguiente interrogante: ¿Estaríamos ante un flagrante error técnico o más bien ante una deliberada "equivocación" en pos de un determinado 


\section{Juan Antonio Sánchez López / Estrella Arcos von Haartman}

efecto emocional?. Lo primero vendría a ser un contrasentido, en tanto en cuanto imputaríamos un defecto, desde luego poco excusable en la concepción de una pintura mural, a quien, según Francisco Pacheco, manejó el fresco con gran destreza y satisfacción ${ }^{20}$, haciendo gala de superior excelencia y magisterio en aquella manera antigua, en que se conoce que era muy práctico, al decir de Antonio Palomino ${ }^{21}$. Por tanto, ¿cuál sería el móvil del dislate?. A nuestro entender la respuesta podría hallarse, de nuevo, en la concepción del espacio de la Capilla Mayor como escenografía pintada. La dialéctica entre llenos y vacíos inherente al alzado habría inducido al pintor a compensar y destacar los segmentos del friso tratados escultóricamente como núcleos macizos, intercalando unas retículas planas, mucho más livianas, cuya impronta tiende a asemejarse a la de unos antepechos revestidos con paños de brocado o damasco. En consecuencia, el pintor no habría realizado otra cosa que trampantojos de tejidos surcados de fantásticos y aparatosos rameados que emularían la textura característica de telas de común uso en la confección de piezas del ajuar litúrgico, en el caso de embocaduras, faldones, colgaduras o frontales de altar. Con esta labor, Cesare Arbassia instrumentalizaría el potencial ilusionista de los frescos brindado por su dominio de la técnica para superar a la arquitectura mediante el triunfo del artificio.

El programa decorativo se transforma y enriquece semánticamente conforme se desciende hacia el emplazamiento del Tabernáculo. El artista utiliza la superficie disponible sobre las enjutas de los arcos abiertos entre los capiteles corintios de los pilares para representar parejas de ángeles mancebos recostados en las enjutas, de atinada factura y cierta gracia conceptual. La predilección manierista por los escorzos, los desequilibrios compositivos y la visión poliédrica del cuerpo se hace patente en la inestable posición "impuesta" a las figuras por el medio punto, "obligándolas" a solapar y contraponer sus movimientos al ritmo marcado por la curvatura del arco, con lo cual se rompe la frontalidad y se consigue la proyección tridimensional de cada personaje mediante el empuje hacia adelante de su pierna izquierda y brazo diestro. Cesare Arbassia plasma unos desnudos juveniles clásicos de complexión atlética, aunque de musculatura escasamente pronunciada en consonancia con un canon corporal esbelto cuya elegancia y dinamismo contrasta con la pesadez de algunas figuras del ciclo de la Pasión. Salvando las lógicas distancias, la visión de estas figuras denotan una declarada dependencia estilística de los miguelangelescos ignudi y genios de la Capilla Sixtina, así como de las estatuas reclinadas de las tumbas de los Médicis en la Sacristía Nueva de San Lorenzo, en Florencia. Aunque carecen de la vehemencia gestual y la versatilidad expresiva que rige la gramática corporal de aquellos ignudi, las figuras de Arbassia, menos temperamentales y bastante más convencionales en cuanto aprisionadas por la inercia y un principio de

20 PACHECO, F.: Arte de la Pintura (Edición, introducción y notas de B. BASSEGODA i HUGAS), Madrid, Cátedra, 1990, pág. 466.

21 PALOMINO, A.: Vidas, Madrid, Alianza Editorial, 1986, pág. 78. 
simetría estricta, sí vienen a coincidir con sus presuntos modelos de la Sixtina en cuanto al papel desempeñado en el plan iconológico del recinto sagrado al que pertenecen. En efecto, al igual que los ignudi, los jóvenes de Arbassia se sitúan en un nivel de transición en la lectura del programa de la Capilla Mayor, a medio camino entre el ciclo histórico narrado a los mortales dentro de su mismo espacio terrenal y la revelación gradual de lo divino que los personajes escultóricos perciben con mayor intensidad conforme se asciende hacia la bóveda. Tal circunstancia les hace comportarse como auténticos intermediarios entre la Divinidad y los seres humanos, manteniéndose cercanos y, al mismo tiempo, distantes de ellos por su condición sobrenatural. Desde tan privilegiada posición, los jóvenes intentan captar la atención de los videntes hacia los frescos de la Pasión de Cristo mediante el gesto indicativo de señalárselos con el dedo. Esta misión les lleva a adoptar un aire introspectivo del cual se deducen sus presentimientos acerca del significado y trascendencia de tales escenas. Dan así la impresión de estar reflexionando instintivamente sobre ellas con contención y serenidad contemplativa, en tanto sus revueltas cabelleras nos aperciben de su facultad visionaria y la fortaleza viril inquebrantable en todo obrar que, según el Pseudo Dionisio Aeropagita, les hace permanecer siempre guiados por el impulso divino que los orienta hacia la potencia supraesencial ${ }^{22}$.

La participación de Arbassia culmina en la pintura de los paramentos de los diafragmas con una ocurrente mixtura de conceptos y géneros pictóricos. De una parte, la simulación de jaspeados y marmoreados surcados por guirnaldas de mirto rodean sinuosas cartelas de rebordes cartilaginosos con espejos ovales en los remates mixtilíneos de cada paño. La rosca de los arcos inferiores incorpora trampantojo marmoreado en tonos rosados fragmentado por clípeos dorados con fondos de serpentina. Especialmente notables son las arquitecturas fingidas que arropan las escenas de la Pasión, constituidas por elementos sorprendentes de gran riqueza visual y excelente ejecución. Con su complicidad Arbassia logra establecer la plena autonomía del ciclo narrativo, sin olvidar tampoco el socorrido recurso al quadro riportato enmarcado por listeles rectos y quebrados como elemento de segregación espacial y definición individualizada de las historias. A la presencia de modillones que delatan el aprecio manierista hacia las formas abstractas y la valoración plástica de los volúmenes puros y desornamentados, se suma el descubrimiento de motivos inéditos tan sugestivos como los híbridos mensulones dórico-toscanos provistos de tenia o regleta bordeada de gotas y volutas rematadas en vivaces cabezas de querubín. Estas inquietas criaturas, poseídas del fuego de la Divinidad, observan al espectador escrutando su interior con atónitas expresiones y ojos profundos y muy abiertos, según corresponde a quienes contemplan el esplendor teárquico que emana del Tabernáculo y han sido infundidos de la sabiduría y los dones del conocimiento,

22 PSEUDO DIONISIO AEROPAGITA: De Coelesti Hierarchia, en Obras completas, Madrid, BAC, 1990, págs. 154 y 182-183. 
cuestión en la que insiste Santo Tomás de Aquino al apostillar: cherubim interpretatur plenitudo scientiae ${ }^{23}$. Son evidentes las similitudes morfológicas entre las testas pueriles de la Capilla Mayor y las pintadas por Arbassia en las Salas de Gregorio XIII del Vaticano, formando parte del molduraje diseñado para los "marcos" de los paisajes integrados en dichas estancias. Es, precisamente, en estos pormenores "secundarios" donde el talento decorador de Arbassia alcanza sus más elevadas cotas al lograr rostros infantiles resueltos con gran frescura gestual y trazo espontáneo, modelándolos con rapidez y casi de manera improvisada sobre el estuco. El pintor confía en la capacidad emotiva del color, la audacia en el control y contraste de las luces y sombras y la soltura técnica a la hora de aplicar el pigmento a base de rápidas pinceladas hábiles, logrando así que la imagen de los querubines quede parcialmente indefinida, diríase más bien desenfocada en consonancia con su pretendida y presunta cualidad de "relieve". Esta técnica sucinta, que permite un mayor o menor grado de definición y naturalismo de las figuras según su posición estratégica en el conjunto mural, ya fue tenida en cuenta por Miguel Ángel en las parejas de putti en estuco fingido de la bóveda de la Sixtina, así como en algunos personajes particulares como el niño portador de la placa a los pies del profeta Daniel o los antepasados de Cristo de los lunetos y triángulos ${ }^{24}$.

Tan espléndida explosión cromática, propiciada en el Teatro-Altar del XVI por los brocados fingidos, ángeles y trampantojos arquitectónicos, admira a Gaspar de Tovar al exclamar: De oro guarnecidos/ aquellos Arcos fuertes/ y otros de Romanillos con primores, / con festones asidos/ de diferentes suertes/ con vivas invenciones de colores/ maiores y menores/ que de cerca mirados, / y mirados de lejos, / son claras como espejos, / y como tienen lazos tan trabados/contemplando la hechural un día entero, a muchos esto dura ${ }^{25}$.

En cuanto a los frescos de la Pasión, de solemnidad monumental, alarde anatómico y cierta frialdad desganada en palabras del profesor Pérez Sanchez, se hacen eco de las fórmulas del manierismo romanista, con profusión de atrevidos escorzos y actitudes bizarras, asumiendo unas constantes asimiladas de la contemplación directa de las grandes obras de dicha corriente sin descartar el manejo de estampas y repertorios grabados, aunque eso sí mostrándose fiel en todo momento a los preceptos de la iconografía sagrada postridentina ${ }^{26}$. La selección de los temas (Institución de la Eucaristía, Oración en el Huerto, Jesús ante Anás, Presentación de Jesús al pueblo por Pilatos y la Flagelación) responde al deseo de favorecer la

23 PSEUDO DIONISIO AEROPAGITA, op. cit., págs. 145-146 y 150; OST, H.: "Borrominis römische Universitätskirche S. Ivo alla Sapienza", en Zeitschrift für Kunstgeschichte, no 30, 1967, pág. 115 y RAMÍREZ DOMÍNGUEZ, J.A.: Edificios y Sueños (Ensayos sobre Arquitectura y Utopía), Málaga, Universidades de Málaga y Salamanca, 1983, págs. 248-253.

24 AA.VV.: La Capilla Sixtina. Una restauración histórica, Madrid, Nerea, 1995.

25 TOVAR, G. de, op. cit. Inserto en MEDINA CONDE, C. de, op. cit., pág. 66.

26 PÉREZ SÁNCHEZ, A. E., "La pintura en la Diócesis malagueña" en AA.VV., El esplendor, 1998, pág. 71 
correspondencia iconológica de los mismos con las tablas pintadas del Tabernáculo. Es muy posible que fuese García de Haro quien estableciera el juego de equivalencias entre los pasajes evangélicos de los frescos y las respectivas prefiguras bíblicas recogidas en los asuntos ubicados al frente del templete sacramental (Elías alimentado por un ángel, Recolección del Maná, Historia de Daniel) ${ }^{27}$. Como puede observarse, del ciclo pasionista se excluyen las secuencias alusivas a la Cruz, cuya presencia glorificada como victoriosum vexillum o lábaro ya había sido incorporada tiempo atrás en las pechinas. Tal circunstancia hacía ahora innecesaria la representación "descriptiva" del suplicio de la Crucifixión sublimado por el ciborium $^{28}$.

Del análisis estilístico de este ciclo evangélico se infiere el talante ecléctico de Cesare Arbassia frente a las propuestas y tendencias de la pintura italiana de su tiempo. En el caso que nos ocupa, la estructura compositiva de las escenas arranca casi siempre (salvo la Flagelación) de las celebérrimas xilografías de Alberto Durero integradas en La Pequeña Pasión (1511). Sobre la base de esta información visual, el italiano manipula, cita, invierte o transforma con absoluta libertad las soluciones aportadas mimetizándolas o, simplemente, recreándolas. Fuente inagotable de inspiración para los artistas posteriores, este repertorio permitió consolidar en las primeras décadas del Quinientos la iconografía de la mayor parte de los temas relacionados con los sufrimientos y desventuras de Cristo. Al adoptarlo como punto de referencia para sus versiones particulares, Arbassia sustituye y recicla los tipos tudescos y la escenografía con resabios medievales del artista alemán por interiores teatrales o perspectivas urbanas utópicas. Tales ambientaciones acogen los personajes del pintor de Saluzzo, impregnados en su mayoría de un peculiar sentido de la monumentalidad miguelangelesca subordinado, en principio, a los criterios de Daniele de Volterra en su personal interpretación del lenguaje cúbico del florentino. En este sentido, no puede olvidarse cómo Sebastiano del Piombo y, especialmente, Daniele de Volterra habían ofrecido una versión particular del miguelangelismo expresada con formas rotundas y volúmenes cubizantes y simplificados, derivando hacia un lenguaje desnudo y evidente de lúcida racionalidad. Una vez perdido el significado dado por Miguel Ángel, este discurso se reveló pronto, según afirma María Calí, como el más adecuado para asumir lo que los tiempos, proclives al compromiso,

\footnotetext{
27 SÁNCHEZ LÓPEZ, J.A.: Historia de una utopía, págs. 44-47.

${ }^{28}$ Como consecuencia de la desaparición de las tablas del Tabernáculo (y con ella la destrucción parcial del primitivo plan iconológico) el ciclo de los frescos de la Pasión adolece de un carácter aparentemente inconcluso (motivado por la ausencia de los temas del Camino del Calvario y Crucifixión) que, hasta fechas recientes ha desconcertado a la historiografía. En el siglo pasado, el canónigo Miguel de Bolea y Sintas creyó ver en tales "carencias" la realidad abortada de un templo oval concebido por Diego de Vergara. Por su parte, la profesora Rosario Camacho propuso como posible complemento narrativo el programa de las vidrieras originales. Véase BOLEA Y SINTAS, M.: Descripción histórica que de la Catedral de Málaga, hizo su Canónigo Doctoral, Málaga, Talleres de Imprenta Arturo Gilabert, 1894, pág. 181 y CAMACHO MARTÍNEZ, R.: Arquitectura y Símbolo. Iconografía de la Catedral de Málaga, Málaga, Real Academia de Bellas Artes de San Telmo, 1988, pág. 40.
} 
junto a la postura dogmática, quisieran atribuirle ${ }^{29}$. Del éxito y continuismo de esta fórmula durante la segunda mitad del Quinientos hablan por sí sólas las creaciones de los seguidores y colaboradores de Volterra (especialmente los pintores de la escuela de Trinitá dei Monti) y las iniciativas experimentales de autores como Luca Cambiaso, cuyos dibujos convierten al cubo en el elemento paradigmático de interpretación de la realidad conduciéndola hasta las fronteras de la abstracción. No obstante, al aplicar el criterio programático y metódico de implicación de la forma cúbica, el pintor de Saluzzo no va más allá de una denotación puramente superficial de aquellos valores de concepto teórico que refrenden la precisa adaptación y concordancia de sus composiciones con el carácter dogmático y el espíritu de la Contrarreforma. Ello explica el escaso vigor expresivo, la fisonomía estereotipada e incluso la torpeza de sus figuras de Cristo, muy encorsetadas en su papel de centro teológico de los episodios. Sin embargo, no sucede así con las gallardas poses y las aristocráticas caracteriologías de los figurantes secundarios situados en un primer plano, cuyo declarado talante profano los libera de toda carga trascendente haciendo gala de una inequívoca intención implicativa de cara al espectador. Por lo demás, los frescos de la Pasión compensan las limitaciones inventivas y falta de genio del pintor mediante la espléndida factura de manos y pies y, sobre todo, el bagaje humanístico y la receptividad que Arbassia posee como un artista ante todo "culto". De ahí podría inferirse su tendencia a construir y entender el planteamiento de las escenas como un prontuario de citas, relecturas y "fusionismos" variopintos que delatan, además de los ya citados, los ecos de autores tan diversos como Giulio Romano, Rosso Fiorentino, Correggio, Parmigianino o el Veronés. Esa misma libertad operativa le insta a adecuar las figuras principales al trasfondo intelectual de la forma cúbica, sin dejar de mantener, empero, convicciones estéticas desfasadas como el culto a la figura serpentina y los juegos de plegados. Por su parte, el código estilístico y el modus operandi del pintor actuarían de factores aglutinantes de tan controvertida mixtura, aportando a los frescos un efecto visual aparentemente homogéneo en su conjunto aunque, como se verá, a veces un tanto forzado en cuestión de detalles.

De izquierda a derecha, el primero de los frescos de Cesare Arbassia tiene por objeto la Presentación de Jesús al pueblo por Pilatos, sin duda la más interesante y conseguida de las composiciones de la Capilla Mayor además de la más veneciana. La xilografía de Alberto Durero proporciona los elementos esenciales de la escena a partir de su división compositiva en dos planos y tres registros de altura. El plano más inmediato sitúa en primer término el tumulto de los habitantes de Jerusalén ante el "espectáculo" que se desenvuelve al fondo, encima de la balaustrada anexa a la galería del palacio desde el que Pilatos (caracterizado "a lo turco", luciendo un pintoresco turbante a tenor de un anacronismo orientalista) muestra a Cristo y

${ }^{29}$ CALÍ, M.: De Miguel Ángel a El Escorial. Momentos del debate religioso en el arte del siglo XVI, Madrid, Akal, 1994, pág. 239. 
pronuncia su Ecce Homo. Sobre la terraza de mármol rosado de una casa adyacente, varias mujeres y ancianos dan réplica con sus ribetes cortesanos al fogoso grupo de jóvenes y guardias situados al pie de la escalinata, mientras en la lejanía la inquieta soldadesca agita sus armas. El pintor de Saluzzo imprime una nota de contemporaneidad al asunto al trasladar el escenario de los hechos a una ciudad renacentista y moderna identificada por las arquitecturas clasicistas, marcando las distancias e insinuando las perspectivas mediante un vacío espacial que, desde el personaje de espaldas, se extiende hacia el foco de atención y se proyecta hacia lo más profundo del episodio perfectamente acotado por el agrupamiento escalonado de los personajes masculinos a la derecha del fresco. Ese interés de Arbassia por subrayar el protagonismo de las gradas como elemento efectista que individualiza, destaca, acerca $y$, a la vez, separa lo principal de lo secundario responde a un principio de organización teatral que debe bastante al esquema iconográfico que la pintura del Quinientos terminará haciendo propio del tema de la Presentación de la Virgen, con el fin de enaltecer la silueta delicada de la niña ascendiendo por sí sola las siete gradas del Templo. De esta manera, Arbassia se separa aquí de Durero y se acerca más al modo de componer de los venecianos.

A propósito de ello, no puede dejar de recordarse el tratamiento paradigmático dado por Tiziano al asunto del Ecce Homo en el lienzo ejecutado, en 1543, para el comerciante flamenco Giovanni Anna conservado en el Kunsthistorisches Museum, en Viena. Como hará Arbassia en el fresco de la Catedral de Málaga, el artista inventa una función total: espacio, escenografía y actores, donde Venecia, teatro y bazar, sirve de decorado para la presentación de Cristo desde el balcón de Pilatos. Al margen de las abismales diferencias de factura, ambos ejemplos sintonizan con la nueva actitud de la Iglesia, cuya oposición a las corrientes heterodoxas y al naciente pensamiento científico le induce a pedir a sus fieles que se aproximen físicamente a Dios. Tiziano hace interpretar esta escena a los venecianos, Arbassia a una población innominada, pero ambos con tanta fuerza y espontaneidad que los personajes se comportan como cualquier multitud arremolinándose y casi empujándose unos a otros para ver mejor el triste "divertimento" de una manera puramente humana, con compasión, con indiferencia, con estupor, con complacencia, incluso con frivolidad. Estilísticamente, y por encima de la torpeza de algunas figuras, el fresco de Arbassia descuella por la brillantez y variedad de sus entonaciones cromáticas, los alardes paisajísticos que posibilitan la integración de la Naturaleza, la Arquitectura y la atmósfera en un mismo cuadro de ambiente y la sofisticación manierista, casi parmesana, del personaje femenino ataviado de intenso amarillo que el pintor parece acertar a plasmar desde el replanteamiento de la figura del sayón que sostiene la Cruz e inquiere a Pilatos en la estampa de Durero. Con ello, define una figura rítmica y esbelta, diferente a la corpulencia y estatismo de las restantes, cuya misión es dilatar el espacio y el grado de implicación de la pintura más allá de sus márgenes físicos mediante el recurso del brazo extendido hacia fuera y el pie posado en el trampantojo del marco. 
El ciclo continúa con la Oración en el Huerto. A excepción de la figura del ángel confortador resuelta en tonos tornasolados, ni siquiera el paisaje nocturno logra distraer de la mediocridad absoluta de la obra. Haciendo suya una vertebración iconográfica común en las últimas décadas del XVI, el fresco tiende a diferenciar sendos estratos. En primer plano, los apóstoles Pedro, Santiago y Juan, este último con el libro de su Evangelio, duermen profundamente bajo extrañas rocas cueviformes. Por encima de ellos, el ángel irrumpe en la escena envuelto en un . aparatoso despliegue de luces doradas hasta quedar frente a la pesada y anodina figura de Cristo. Al fondo, entre la vegetación, el cortejo guiado por Judas desde Jerusalén cruza la puente del torrente Cedrón en dirección a Getsemaní. Como en el caso anterior, el débito dureniano convive con una serie de convencionalismos compositivos secundados, entre otros, por Tiziano o Correggio y difundidos por interpretaciones grabadas como las debidas a Giulio Bonasone y Cornelis Cort quién, por cierto, trasladaría a la estampa un cuadro de temática similar realizado por Federico Zuccaro.

Tratándose de un recinto eucarístico, la Última Cena ocupa el lugar de honor de la cabecera, en consonancia con el clima de exaltación que, a raíz de Trento, acrecentó en España el esplendor de las fiestas del Corpus y el auge de las Hermandades Sacramentales. Con mínimas variantes que atañen al replanteamiento de los personajes secundarios de los lados, Arbassia reproduce la misma composición pintada años atrás, hacia $1583-1585^{30}$, en el testero de la puerta de acceso al Tabernáculo de la Capilla del Sagrario de la Catedral de Córdoba, la gran empresa promovida por el obispo Antonio de Pazos y Figueroa como homenaje a la Eucaristía y a los Mártires de la ciudad. Uno y otro fresco todavía suscriben los aires del Cenáculo leonardesco, aunque acomodándolos en la versión malagueña al esquema envolvente brindado por el grabado de Alberto Durero, cuyo eco perdura en un buen número de estampas abiertas en los talleres flamencos y romanos del Quinientos incluidas como ilustración en breviarios, misales y libros litúrgicos. En coherencia con el decoro, Arbassia atempera los matices dramáticos inherentes al instante en el que Cristo anuncia la traición de Judas, por un clima distendido más acorde al momento de reflexión demandado por el acto solemne de la institución sacramental. Un ampuloso cortinaje verde hace las veces de telón (en la versión cordobesa la cortina rematada en baldaquino se abre a un paisaje) bajo el cual se descubre la contenida agitación corporal y el intercambio de gestos dialogantes de los personajes, acompasados por los complicados drapeados. En su afán de subrayar la doblez de

\footnotetext{
30 PÉREZ LOZANO, M.: "Los programas iconográficos de la Capilla del Sagrario de la Catedral de Córdoba", en Cuadernos de Arte e Iconografía, IV-8, 1991, págs. 57-64; CONTI, G.: "Las pinturas del Sagrario de la Catedral de Córdoba”, en AA.VV.: Homenaje a Dionisio Ortiz Juárez, Córdoba, 1991, págs. 45-57 y NIETO CUMPLIDO, M.: La Catedral de Córdoba, Córdoba, Cajasur, 1998, págs 384-
390.
} 
Judas, Arbassia somete su figura a un rebuscado escorzo que le lleva a descoyuntar el tronco y la cabeza para enfatizar su siniestro ceño fruncido y la mirada torva que inquiere con descaro al espectador. El peso de la tradición popular, perpetuada por el teatro desde los tiempos medievales, se hace sentir al contemplar a Judas sujetando la bolsa con las treinta monedas de plata esbozando con la mano el gesto diabólico que delata su condición de servidor del mal, mientras la soga se enrosca alrededor de ella, (como si de una serpiente se tratara) anticipando su futuro arrepentimiento y suicidio. Arbassia elimina la jofaina y el aguamanil de la versión primitiva para introducir la imagen tópica del perro que ya Plinio el Viejo consideraba trasunto virtuoso de una fidelidad sin límites. El animal ,discretamente sumido entre las sombras, permanece recostado en la estrecha abertura triangular existente entre uno de los apóstoles del primer término y el propio Judas, al que la presencia del perro sirve de antítesis. Al fondo, dos personajes a la derecha de Cristo proceden a servir la mesa. Uno de ellos, con barba y elegante indumentaria a modo de gentil hombre, podría interpretarse como presunta imagen del artista dada la coincidencia de sus facciones con los autorretratos pintados por Arbassia, en 1602, en su casa de Saluzzo con la intención de asimilar su espacio privado a un personal Templo de la Inmortalidad en el que perdurase su fama de pintor alquimista ${ }^{31}$.

Contrapunto y complemento iconográfico a los pasajes del proceso político de Cristo ante Herodes y Pilatos son los correspondientes a su proceso religioso por parte de las autoridades religiosas y pontífices del Sanedrín. La comparecencia de Jesús ante Anás es abordada por Arbassia fusionando elementos de sendas estampas dedicadas por Durero al juicio ante Anás y ante Caifás. De la segunda extrae la idea general para el grupo de Cristo maniatado rodeado de soldados, al que imprime un dinamismo más intenso el gesto enérgico del sayón que sale al paso del protagonista y le profiere la célebre bofetada de tanta resonancia en el ámbito de la dramaturgia y la escultura procesional ${ }^{32}$. Otra xilografía proporciona la composición básica del estrado con el pontífice y su séquito que Arbassia reconvierte en una ampulosidad cortesana claramente deudora de los ambientes áulicos frecuentes en la pintura del Veronés. Al igual que en el fresco de Cristo ante Pilatos, Arbassia ofrece en el aguerrido personaje masculino del primer término un pormenor de hermosa factura que viene a corroborar las disparidades cualitativas existentes en el ciclo, en este caso nuevamente amortiguadas por una radiante paleta.

En la Flagelación, Cesare Arbassia ofrece una pieza sujeta por completo a remanentes de formalismo académico, visibles en el pronunciado dibujo y el tratamiento escultórico de los personajes, singularmente, del musculoso desnudo de Cristo. La composición tampoco es original pues en ella el italiano simplifica y plagia, en

31 BLÁZQUEZ MATEOS, E.: "La morada filosófica”, págs. 91-92

32 DERBES, A.: Picturing the Passion in Late Medieval Italy. Narrative Painting, Franciscan Ideologies, and the Levant, Cambrigge University Press, 1996, págs. 72-93. 
honor a la verdad con escaso acierto, el lienzo similar realizado, hacia 1585-1586, por su compañero y amigo Federico Zuccaro para el segundo cuerpo del Retablo Mayor de San Lorenzo de El Escorial. En cualquier caso, es interesante destacar la pervivencia entre los pintores italianos del esquema iconográfico popularizado desde los tiempos medievales por las Cofradías de Battuti o Disciplinati que configura el episodio de la Flagelación mediante un único grupo de gran cohesión volumétrica formado por Cristo y dos verdugos que lo golpean con ademanes tendentes a la simetría y la contraposición rítmica ${ }^{33}$. Lo demás viene añadido por la imaginación, en el caso de los sayones arrodillados en primer término, las arquitecturas clásicas y la imagen de la rotonda al fondo con su cúpula evocadora del Panteón de Roma y la figura del niño horrorizado ante el suplicio, añadida por Arbassia como presunta "invención" que enfatiza el dinamismo centrípeto de la escena. La vocación contrarreformista de la obra le insta a suscribir la variante iconográfica de la Flagelación protagonizada por la columna troncocónica baja que recrea el semifuste de pórfido depositado por el cardenal Giovanni Colonna, en 1223, en la Iglesia romana de Santa Práxedes. Esta supuesta reliquia de la Flagelación serviría al propósito postridentino de propiciar una interpretación del episodio más dramática y "arqueológica", en la que Cristo, arqueado por el dolor, se mostraba indefenso frente a toda suerte de golpes. En este sentido, las obras de Zuccaro y Arbassia, entre otros, anticipan el carácter canónico y oficialista impreso a dicho formulismo a raíz de la publicación del grabado del Cristo azotado inserto en la obra de Alphonso Paleotti (sobrino del cardenal Gabrielle) y Daniele Mallonio, Iesu Christi Crucifixi Stigmata Sacrae Sindone Impressa, publicada en Venecia en 1606, a modo de compendio erudito sobre las lesiones e instrumentos de tortura de la Pasión ${ }^{34}$.

\section{La repristinación del XVIII}

Pocos años logró mantener intacto el Altar del XVI su programa decorativo. El profundo disgusto del Cabildo ante la paralización de la Fábrica de la Catedral decretada por García de Haro no le hizo ver con buenos ojos el tabernáculo costeado por el obispo y decorado por Arbassia. Los Capitulares siempre habían tenido sus propios planes sobre el particular al haber iniciado ya, en 1587, los preparativos para su construcción al ordenar la traída de piedra desde Antequera ${ }^{35}$. La apuesta por los materiales nobles brindaba a la corporación la excusa perfecta para eliminar a la menor oportunidad una pieza que, en honor a la verdad, no les traía precisamente

\footnotetext{
${ }^{33}$ SCHAPIRO, M.: Estudios sobre el Arte de la Antigüedad tardia, el Cristianismo primitivo y la Edad Media, Madrid, Alianza Editorial, 1987, págs. 321-323.

34 SÁNCHEZ LÓPEZ, J.A.: El alma de la madera. Cinco siglos de Iconografía y Escultura procesional en Málaga, Málaga, Hermandad de Zamarrilla, 1996, págs. 142-145.

35 A.C.M., leg. 1027, pza. 2, Actas Capitulares, lib. 13 (1579-1588), fol. 242 r., Cabildo de 25-Mayo-1587.
} 
buenos recuerdos. Con ello, se producía la primera intervención traumática en la configuración estética primitiva de la Capilla Mayor. No en balde, la desaparición del templete rompía la equivalencia semántica de los frescos de la Pasión con el núcleo iconológico del recinto, mermando su simbolismo mesiánico. Las discusiones y dudas para sustituirlo se dilataron a lo largo del Seiscientos, pese a la existencia de dos trazas dadas por el jesuita Francisco Díaz de Ribero ${ }^{36}$ (h. 1659-1663) y Alonso Cano (1665) ${ }^{37}$. Hacia 1689-1691, el Cabildo levantaba sobre el altar una gigantesca estructura lignaria, semejante a una mampara poligonal, adaptada como un retablo a la estructura semidecagonal de la cabecera, conservando al mismo tiempo el sistema centralizado de un templete. El arquitecto de madera José Fernández de Ayala y el escultor Jerónimo Gómez Hermosilla materializaron un Tabernáculo con los santos protectores de la ciudad de Málaga, en el que, posiblemente, fusionaron los elementos más llamativos de las trazas anteriores ${ }^{38}$. Esta obra quedó sin dorar y su frustrante "terminación" canalizó nuevas propuestas para sustituirlo en el XVIII. A juzgar por la documentación y el testimonio del Mayordomo y Superintendente de la Fábrica Mayor, Francisco Barbán de Castro, sus despojos o fragmentos arquitectónicos que se están perdiendo y rodando por los suelos en varios sitios en que se amontonaron fueron utilizados como material de acarreo para distintos retablos construidos en la Catedral a partir de la década de $1770^{39}$. Así sucedería con el dedicado, en 1772, por la Capilla de Música de la Catedral a su patrón San Blas ${ }^{40}$.

En tanto se desmantelaba definitivamente, la mayor parte de la estructura arquitectónica de la capilla permaneció oculta por tan aparatoso edículo de madera, lo cual conllevó el olvido del conjunto de pinturas murales y el deterioro de algunos elementos como las basas de pilastras y columnas. Este ostracismo finalizaría el 31 de octubre de 1768, cuando el Cabildo aprobaba distintas disposiciones económicas al plantearse acometer la compostura de capilla maior y nuevos órganos correspondientes a la suntuosidad de la $\mathrm{Yg}^{a}{ }^{41}$ En 1769, previo informe del Maestro Mayor,

\footnotetext{
${ }^{36}$ ARANDA, G. de, El Artífice Perfecto ideado en la vida del V. Hermano Francisco Díaz del Ribero, coadjutor formado de la Compañía de Jesús, Impressa en Sevilla por Iván Pérez Berlanga, Impressor de Libros en las Siete Revueltas, 1696, págs. 205-206.

${ }^{37}$ A.C.M., leg. 1035, pza. 1, Actas Capitulares, lib. 31 (1664-1670), fol. 114 v., Cabildo de 15-Julio-1665. Véase CAMACHO MARTÍNEZ, R., "Alonso Cano y Málaga" en AA.VV., Alonso Cano. Virgen del
Rosario,Fundación Argentaria, Madrid, 1997, págs. 14-18.

${ }_{38}$ Archivo Temboury Málaga, leg. 67 :'’Edificios religiosos", Sección Catedral, Asunto Tabernáculo, s/f., pza.: Copia de veinte y ocho de Mayo de este año de mill seisc.s y ochenta y nuebe de los gastos causados en Fábricas Mayores en esta semana para la obra del Tabernáculo de esta St ${ }^{a} \mathrm{Ig}^{a}$.

${ }_{49}$ A.H.P.M., Escribanía de Joaquín Fernández de la Herrán, leg. 3067 (1771), fols. 954r.-954v..

A.C.M., leg. 1049, pza. 1, Actas Capitulares, lib. 51 (1769-1772), fols. 564v.-565v., Cabildo de 9-Octubre1772. La delicada representación escultórica del titular, realizada por Fernando Ortiz, se ubicó en un altar, para cuya hechura se concedió a los músicos igual permiso para usar de algunos fragmentos del tabernnáculo antiguo $p^{a}$ el adorno de dicha Capilla, considerando la cortedad de sus sueldos y no poder estos sufragar
$o$ desterrar fondo $p^{a}$ retablo.

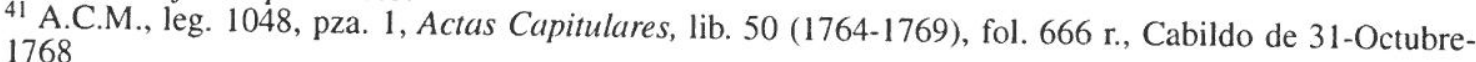


Antonio Ramos, se perfilaban dichas acciones ${ }^{42}$ mandando pintar con brocha la Capilla maior y bóveda del Cruzero, como el resto de la $\mathrm{Ig}^{a}$, sin mescla alguna de oro, suspendiendo por aora resolber en quanto a renovar las estatuas y pinturas, asta acordarlo el Cabildo. Por fin, el 5 de Junio de dicho año se adoptaban diligencias concretas que indican un cambio de planes, en tanto la desnuda limpieza de los muros inicialmente prevista se modifica ante la pretensión de:

...hechar golpes de oro en los chapiteles y basas de columnas, y más lo que parezcan conducentes a los Sres. Diputados, poniendo todas las estatuas y nichos como de alabastro, ... ... Y que las pinturas de la Passión permanezcan, retocándose éstas en la parte que juzguen lo necesiten, adornándolas figurando marco al oro; y la misma Diputación tomando los dictámenes que le parezcan convenientes facilitará la disposición de un Tabernáculo por aora para el uso, quitando el actual y dejando la colocación de la madera de éste al prudente arbitrio de la Diputazión. Y en el interin se disponga el altar en el trascoro, asta las puertas principales y la Sacristía a su lado, quedando a la Diputación la ejecución de ésto, señalar sitio para la ciudad, Púlpito y demás necesario ${ }^{43}$.

La voluntad de restaurar y mantener el programa renacentista convive así con la intención de conferir un cambio de fisonomía a la arquitectura del recinto a costa de subrayar con oro las directrices del alzado, destacándolo sobre fondo blanco y decorando los rehundidos y frisos a base de insulsos rameados, de ruda factura y similares a grutescos ordenados simétricamente. Dado que la corporación había depositado su confianza en una comisión en la que delegaba la facultad decisoria sin necesitar de acudir al Cabildo sobre menudencias de esta disposición, sus componentes, Pedro Cruz, Francisco Enríquez, Nicolás García y Francisco Santos de San Pedro, encomendaban estas tareas, el 29 de Julio de 1769, al maestro Alonso de Ribera. Una de las dudas suscitadas durante la marcha de las obras es la tocante a la pintura de las estatuas y bustos, al plantearse el dilema de fingirlas de alabastro o mármol con ribetes o sus ropas de colores con guarniciones de oro y sus carnes de encarnación ${ }^{44}$. En cualquier caso, la apuesta final por la policromía de las esculturas no minimiza el impacto visual inherente al triunfo de la bicromía blanco

\footnotetext{
42 A.C.M., leg. 1049, pza. 1, Actas Capitulares, lib. 51 (1769-1772), fols. 27r.-27v. y 30r., Cabildos de 6 y 13-Marzo-1769

43 Ibídem, fols. 58v. y 63 r., Cabildo de 5-Junio-1769. Los problemas de espacio derivados de la obra afloran meses más tarde, cuando el obispo José Franquis Lasso de Castilla comunica al Cabildo la dificultad de impartir al pueblo la bendición papal el segundo día de Pascua, considerando lo estrecha que está la disposición de el Altar y quisiera se mudasse. Ibídem, fols. 118v.-119r., Cabildo de 21-Diciembre-1769.

44 Ibidem, fols. 59r.-62v.
} 
y oro que imprimió una nueva configuración estética al santuario renacentista más acorde con las preferencias dieciochescas. El memorial de condiciones es sumamente explícito, en cuanto testimonio excepcional del apuntado cambio de gusto. Así, se determina someter las zonas altas de la Capilla y la bóveda presbiterial a una simple restauración, dorándose según y conforme oy están por estar bien repartido el oro de buen gusto. La unanimidad se rompe gradualmente conforme el texto se adentra en superficies del conjunto como las cuatro pilastras:

...que caen a lo interior de la Capilla maior, las que no tienen ni santo ni adorno alguno de medio relieve; sólo están sus fondos o planos adornados con pinturas de barias colores las que se dorarán sus talones hasta la cornisa del primer cuerpo y en lugar de los colores sobre el campo blanco o color que se determinase se dorarán todo su ámbito con el follaje de romanillo, según y conforme estubiesen los arcos y las demás pilastras del cascarón.

El tono se vuelve tajante al aludir a áreas especialmente "conflictivas":

...el friso donde están colocados ocho santos de medio cuerpo, ....... guarnecido entre los santos con un romanillo de colores, los que se quitarán y quedará todo el color blanco ... ... ..... y en las pilastras se dorarán los talones pero las mochetas ni el resalto no si no es de blanco por la mucha confusión que ai allí de oro. Se sigue las bazas de columnas y pilastras las que están doradas todas ellas las que se dorarán como están, así bazas de colunas como de pilastras. Entre dhas. colunas ai cinco pinturas de la Pazión con sus marcos dorados con recodos y con el color sobre el oro de los marcos finjidas molduras. Se hará en el dorado lo mismo que están en dhos. marcos y sobre ellos ai unos adornos de cortesa de colores, los que se dorarán y en su lugar se harán otros de mejor gusto finjiendo piedra. Siguen los cinco arcos entre los pilares que forman el cascarón que sus faxas están doradas y en sus clabes forman como un óbalo de pintura y se harán dorando sus faxas y quitando los colores... ${ }^{45}$

Cuando, en abril de 1770, Alonso de Ribera culminaba su labor la satisfacción de la Comisión competente por el resultado de la obra era tal, que al comunicarlo el Cabildo requería su parecer para que se adornassen también los Escudos de las Armas reales sitos sobre las Puertas y frente del ámbito del Cruzero, la rexa del

${ }^{45}$ Ibídem, fols. 61r.-61v. 
Altar mayr y guardapolvos de los púlpitos, como así sucedería ${ }^{46}$. Es evidente que con esta iniciativa el Cabildo verifica una auténtica repristinación de la Capilla Mayor, convertida desde el reinicio de las obras catedralicias en 1719 en la punta de diamante y el "espejo" que justificará el criterio historicista seguido a la hora de culminar el edificio más de un siglo después de su consagración. Si de lo que se trataba era de preservar la unidad estilística del proyecto era ineludible primar ahora lo arquitectónico sobre lo escenográfico, reivindicándose un retorno a los ideales de pureza y pulcritud que, curiosamente, viene a coincidir con el experimentalismo renacentista y su inquietud de conciliar el aspecto de templo antiguo y clásico con el espíritu de elevación del período gótico, renovando, asimismo, el concepto de luminosidad. De ahí, la reiterativa llamada al orden y el retorno a la claridad propugnado en los documentos, lo cual implica negar la autonomía y facultad escénica al ornamento pintado y someterlo a una disciplina racionalista neo-clásica que reduce sus funciones a un mero papel de aditamento. No obstante, la preservación de los frescos de la Pasión hizo de la Capilla Mayor lo que hoy es: un palimpsesto sujeto entonces a la controversia y ahora al debate abierto por los resultados de la intervención conservadora que nos ha arrojado nueva luz sobre la compleja historia de un monumento ${ }^{47}$. Mientras la sociedad y los agentes culturales de la ciudad determinan si contestar a tan silencioso interrogante (a ese ¿y ahora qué?) con valentía, prudencia o cobardía ángeles mancebos, mármoles y bambalinas fingidas y querubines duermen otra vez bajo su pantalla de cal aprisionados entre redes de frondosas ramas doradas. Si bien, el proceso es ya irreversible pues, para satisfacción de todos, sabemos que están ahí y ojalá un día se establezcan los criterios adecuados para "despertarlos" definitivamente y continúen sorprendiéndonos tal y como ya lo hicieran.

\section{TRATAMIENTO, INTERVENCIÓN E INVESTIGACIÓN DE LOS FRESCOS (Estrella Arcos)}

Conocer, interpretar y difundir los significados culturales y valores históricos y estéticos de las obras de arte constituye uno de los aspectos fundamentales de la metodología de la investigación a la hora de formular proyectos concretos de intervención. Por otro lado, los resultados o conclusiones extraídas mediante las técnicas e instrumentos de examen físico permite la formulación de conclusiones más precisas que suponen la puesta al día y/o revisión histórica, en su caso, de las obras intervenidas, permitiendo en ocasiones aportaciones fundamentales para la historiografía del arte. Es bajo estas premisas donde se justifica el análisis, en el presente apartado,

46 Ibídem, fol. 150v., Cabildo de 5-Abril-1770.

${ }^{47}$ ARCOS VON HAARTMAN, E. y GALLEGO MARTÍN, J.: “¿Recuperar el altar del s. XVI?”, en AA.VV.:

Retrato de la Gloria, págs. 111-123. 
de la técnica de ejecución y de los resultados obtenidos tras la actuación restauradora en la Capilla Mayor de la Catedral, tanto más si se considera la problemática surgida a partir de la aparición fortuita de las pinturas subyacentes, no del todo desconocidas si se tiene en cuenta los datos aportados por los documentos, pero refrendadas en imágenes a partir de las catas abiertas durante el proceso de limpieza. De hecho, bien podían haberse considerado desaparecidas ya que los revestimientos, como "estratos de uso" están sujetos a operaciones de contínua renovación. El ámbito de actuación ha abarcado desde la base de las pilastras hasta la línea del entablamento superior, a partir del cual arrancan nuevas columnas que a través de nervios se desarrollan hasta la cúpula. En este espacio se encuentran las manifestaciones pictóricas, escultóricas y ornamentales que han sido objeto de restauración. Dado el desarrollo del presente artículo, se obviarán los datos referentes a esculturas, dorados y estucos para centrarnos en la problemática de las pinturas al fresco, en su doble vertiente, como ya se ha indicado, de análisis de la técnica de ejecución y procesos de conservación-restauración.

\section{El fresco como técnica}

La decoración parietal es una de las manifestaciones artísticas más antiguas que se conocen. La razón de este planteamiento en principio es bien simple: desde época prehistórica, en abrigos y cuevas, hasta las civilizaciones actuales, la posibilidad de utilizar todo tipo de muro (ya sea en piedra natural o labrada, tapial, adobe, ladrillo u hormigón) ha supuesto el aprovechamiento de un soporte continuo, fijo y fiable para ser revestido o decorado con diferentes finalidades -ya de protección, ya ornamental, simbólica o propagandística. Esta continua presencia ha favorecido las abundantes referencias en tratadistas de todas las épocas. De su estudio y análisis se deducen los diferentes métodos de ejecución a lo largo del tiempo y las soluciones autóctonas dependiendo de las posibilidades del medio natural y del entorno geográfico.

Sin embargo, a pesar de estas variaciones geográficas o temporales, siempre motivadas por el tipo de material disponible, los conocimientos transmitidos para su ejecución o la finalidad de su aplicación, se encuentran en los escritos de todas las épocas unas referencias hacia los sistemas de elaboración coincidentes tanto en cuanto son fruto de la experiencia, la tradición y la reflexión. De este modo, desde Plinio, Vitruvio, Teófilo o Cennino Cennini hasta Vasari, Carducho, Pacheco, Pozzo o Palomino, por citar sólo algunos autores, ofrecen exhaustiva referencia acerca de las bondades de la pintura mural, las dificultades que emanan de su realización, las habilidades indiscutibles que deben tener sus ejecutores, los materiales más adecuados y el proceso de ejecución, así como los problemas derivados de la falta de método o provenientes del entorno. El valor de estas aportaciones reside fundamentalmente 
en la transmisión de unos conocimientos ya bien consolidados en la época de César Arbassia y que autores como él aplican con rigor en sus creaciones, tal y como se definirá a continuación.

Es importante corregir un error frecuente entre los más profanos y que es el de definir con el término "fresco" a toda pintura mural. Se trata de una técnica pictórica particular sobre muro que se distingue de otros métodos por relacionarse con el proceso de carbonatación del mortero, en el que se introduce el pigmento. Es este factor elemental el que la distingue de pintura a la cal o mezzo fresco y pintura a secco con óleo o temple. Esta técnica se realiza cuando se hace uso del principio de fijar el color, (pigmentos disueltos en agua obteniendo una suspensión) aplicado sobre el enlucido mientras está todavía húmedo, por medio de la carbonatación de la cal según la fórmula: $\mathrm{Ca}(\mathrm{OH}) 2+\mathrm{CO} 2=\mathrm{CaCO} 3+\mathrm{H} 2 \mathrm{O}$. O, lo que es lo mismo, cuando la cal del enlucido combinándose con los gases carbónicos del aire se transforma en carbonato cálcico, convirtiéndose en una superficie compacta que incluye dentro de sí el color. El examen microscópico revela una clara penetración del pigmento en los intersticios de las partículas que componen la superficie, en contraste con el tipo de adhesión, más superficial, de las pinturas al óleo y al temple. Para que tal proceso pueda completarse con buenos resultados, el secado del fresco (la eliminación del agua) debe realizarse de manera lenta y uniforme.

Por todo ello el método tradicional del buon fresco supone un proceso de inicio y terminación de aplicación del color en un intervalo de tiempo definido y limitado, de modo que se asegure en la obra todas sus cualidades estéticas y de resistencia exigibles. El momento idóneo para pintar se sitúa en el comienzo del secado del intonaco, en torno a las 2-3 horas desde su aplicación, periodo que varía según la estación, la humedad del lugar, la ventilación y otros factores externos, durante el cual el intonaco comienza a deshidratarse y contraerse. Durante este intervalo de tiempo el agua de inhibición que ha servido para provocar la mezcla de los componentes del mortero migra hacia el arricio y el soporte murario, dejando los poros superficiales libres. Ello permite que el agua del pincel sea absorbida y penetre dejando el pigmento depositado en la superficie. Al mismo tiempo, el secado del mortero ha iniciado el proceso fundamental de apresar el ligante contenido en él, el hidrato de calcio, que permite al mortero endurecer y mutarse en un material compacto y resistente, obteniéndose por la reacción antes formulada. La cal presente en la superficie del intonaco y, sobre todo, la que aporta el agua durante la fase de evaporación, engloba al pigmento y al carbonatar le da gran resistencia ante los agentes externos y produce un óptimo resultado estético:

Esta es la que obra con sola el agua, y los colores, con la virtud atractiva del estuque fresco, que cubre la superficie, donde se pinta; y es la más robusta y valiente de todas las maneras de pintar; así por el gran magisterio, con que pide ser obrada, como por no rendirse 
La capilla mayor de la Catedral de Málaga: palimpsesto y escenografía pintada

a las inclemencias del tiempo...Consiste, finalmente, la maravillosa operación de este linaje de pintura en la virtud atractiva del estuque (formado de cal y arena) con cuyo ardor, al parecer, insaciable, chupa y embebe en sí la humedad, que llevan los colores, con tal violencia, que de ahí se sigue el incorporar, y unir en sí mismo aquellos colores... ${ }^{48}$

Considerando el breve intervalo de tiempo durante el cual es conveniente extender el color, el pintor decide el espacio conveniente para ejecutar la obra. Se trabaja, por tanto, con giornatas, como se denominan los espacios determinados elegidos para ser ejecutados cada vez. Los márgenes de estos espacios tienen un perfil en diagonal, de modo que permitan una mejor unión con las adyacentes y suelen ser levemente visibles, sobre todo bajo luz rasante, porque se superponen. A propósito de ello, Cennino Cennini advierte: ... pero, si puedes, no remolonees, porque trabajar al fresco significa seguir un ritmo rápido, pues el temple de un dia es el más fuerte, el mejor y más agradecido trabajo que se puede hacer ${ }^{49}$. No en balde, Vasari sentencia:

Una de las formas más hermosas de la pintura es la que se hace sobre muro y también la más espontánea, porque debe resolverse en un dia sin que se pueda retocar lo realizado ${ }^{50}$.

En cuanto a soporte y enlucidos, el muro puede ser de piedra o ladrillo, pero no mixto, porque tal variedad provocaría diferenciación en el fresco; debe estar bien seco y presentar una superficie rugosa para permitir la aplicación del mortero de cal y arena. La cal obtenida de la cocción a $850-900^{\circ} \mathrm{C}$ de la caliza compacta y pura $(\mathrm{CaCO} 3=\mathrm{CaO}+\mathrm{CO} 2)$ debe ser disuelta con una cantidad conveniente de agua y dejarla reposar bastante tiempo para conseguir una hidratación completa y homogénea $(\mathrm{CaCO}+\mathrm{H} 2 \mathrm{O}=\mathrm{Ca}(\mathrm{HO}) 2)$. La arena debe ser silícea y de río y no debe tener arcilla, pues origina exfoliaciones. Este material químicamente inerte tiene la función, a parte de aumentar la masa del mortero, de darle mayor cohesión, consistencia y un aspecto característico a parte que favorece, aumentando la superficie de contacto, la interacción entre la cal y el anhídrido carbónico. La dureza final del mortero es una característica que depende de la lentitud de la deshidratación y de la calidad de la arena: la de cuarzo permite un mortero más duro que la calcárea. Para el primer

\footnotetext{
${ }^{48}$ PALOMINO, A.: El Museo Pictórico y Escala óptica, Madrid, Aguilar, 1988, pág. 143 (Libro I, cap. VIII) 49 CENNINI, C.: Tratado de la Pintura (El Libro del Arte), Barcelona, Sucesor de E. Meseguer editor, 1968, pág. 58 (cap. LXVII)

50 VASARI, G.: Las vidas de los más excelentes arquitectos, pintores y escultores italianos desde Cimabue a nuestros tiempos (Antología), (Edición a cargo de J.Mª MONTIJANO y Mª T. MÉNDEZ BAIGÉS), Madrid, Tecnos, 1998, pág. 114 (cap. XIX)
} 


\section{Juan Antonio Sánchez López / Estrella Arcos von Haartman}

revoque (llamado habitualmente arriccio) se utiliza cal grasa con arena de mayor granulometría en una proporción 1:2-3. Con agua se obtiene un compuesto que se hace relativamente consistente y muy homogéneo. El espesor gira entre 1 a $3 \mathrm{~cm}$. El enlucido o intonaco, destinado a recibir el color, se compone de arena fina, polvo de mármol y cal a partes iguales y se aplica sobre el revoque previamente humedecido; éste debe estar bien húmedo y mantenerse así mientras dure el trabajo de dar color, por lo que sólo puede aplicarse sobre el muro en la superficie que se puede colorear en un día.

Como deben resistir la acción cáustica de la cal, no todos los pigmentos son aptos para su uso en esta técnica. Son preferibles los colores de origen mineral: blanco de San Juan (carbonato cálcico) y cal apagada (hidróxido de calcio) para el blanco; ocres naturales y tostados para el amarillo y el rojo, tierras para el rojo y el verde, lapislázuli para el azul, sombra natural y tostada para los marrones. Para el negro se utiliza negro de marfil o de hueso, o de carbón de vid. Para Vitruvio: En cuanto a los colores, si se aplican con todo cuidado sobre el enlucido fresco, no desaparecen, sino que se conservan indefinidamente ${ }^{51}$. Por su parte, Palomino apostilla: Aquellos colores, que verdaderamente son homogéneos, o semejantes a su naturaleza, pues consideradas las tierras minerales, son de la naturaleza de la arena; $y$ considerando el blanco, que con ellos se gasta, es la misma cal ${ }^{52}$.

Como complemento al buon fresco definido anteriormente, el mezzo fresco se realiza con un grado de carbonatación de la argamasa más avanzado. Es posible en este caso obtener una película pictórica suficientemente ligada por el carbonato de calcio utilizando colores aglutinados en agua de cal, que funcionará como ligante: se denomina entonces pintura a la cal. Esta característica implica que, mientras en la técnica del buon fresco la cal del soporte es el aglutinante, en la pintura a mezzo fresco ésta constituye el medium del color pero no del soporte. El resultado es una pincelada más rugosa y empastada. Por otro lado, la pintura a secco se realiza sobre un intonaco que ha completado su carbonatación. Este recurso nace de la necesidad de utilizar pigmentos poco estables ante la causticidad del hidrato de calcio, así como de retoques, ampliaciones o correcciones posteriores o bien para unificar las líneas de separación de las jornadas. En cuanto a los sistemas de trasvase de los dibujos preparatorios al muro, han evolucionado también a lo largo de la historia, pasando de la técnica de la sinopia, al estarcido o el cartón.

\section{Los frescos de Cesare Arbassia y su técnica}

Conocido ya en su época como fresquista, Cesare Arbassia viene a Málaga para ejecutar las pinturas del altar mayor de la Catedral y de la Capilla de la

51 VITRUVIO POLIÓN: Los diez libros de Arquitectura, Barcelona, Alta Fulla, 1987, pág. 174 (Libro VII, cap. III)

52 PALOMINO, A.: op. cit., pág. 147 (Libro I, cap. VIII) 
Encarnación, junto con otras obras pictóricas (Tríptico de la Anunciación, trazas de las andas para la Custodia de asiento, dorado y pinturas del Tabernáculo...). Confirmado por la analítica físico-química, la ejecución de las obras se realiza con técnica de buon fresco, ya definida anteriormente, con retoques posteriores a secco. Los cinco paneles pictóricos que componen el conjunto tienen dimensiones similares $(175 \mathrm{~cm} \times 106 \mathrm{~cm})$ y se enmarcan con una moldura plana perimetral que combina dos tonos de dorado. Se ubican en los diafragmas de refuerzo de los pilares, a media altura, sobre arcos de medio punto. En torno a ellos, unos remates superiores e inferiores de traza sinuosa y floral arriba, con cintas y lazos abajo, enriquecen la visión de conjunto. Es importante indicar la influencia que en su actual estado de conservación ha tenido el hecho de que su ubicación sea exenta de muros sustentantes y sin contacto con el suelo, lo que le ha evitado nefastas influencias directas de humedades, aunque no ha impedido problemas de condensación sobre la superficie y de depósitos de suciedad provenientes del propio uso de culto (humo, hollín, polvo, afluencia de visitantes y feligreses...).

Sobre el muro soporte se han aplicado una o dos capas superpuestas realizadas con mortero de arena, entre los que se aprecian restos silíceos de caparazones fosilizados (probablemente foraminíferos) y granos calcíticos, encontrándose tanto en una matriz mixta de yeso y calcita o en una matriz de cal carbonatada de textura microcristalina, típicas de la técnica al fresco. Una vez incorporada la primera capa, se procede a humectarla y aplicar la segunda, que se extiende exclusivamente en el espacio elegido y con las dimensiones adecuadas para completar la ejecución pictórica. En cualquier caso, las superficies de las jornadas no parecen grandes y suelen tener sus límites en los contornos de las figuras. La única técnica detectada en esta pintura para el traslado al muro de los bocetos preparatorios es el método de incisión, aunque muy probablemente se acompañara de un estarcido previo, en base a los restos de carboncillo (spolvero) encontrados en algunas muestras, aplicado a través de las perforaciones realizadas sobre el cartón siguiendo las líneas del dibujo preparatorio. Después, para asegurar que estos trazos no se hicieran imperceptibles, durante el proceso de pintura se incidía en ellos con una punta metálica no muy aguda para producir un pequeño surco. Éstos se aprecian fácilmente en la totalidad de la capa pictórica al ser iluminada la superficie con luz rasante.

Sobre la aplicación del color al fresco se han observado la presencia de los ya nombrados retoques sobre el revoque ya seco, con los cuales el autor puede dar el acabado con el nivel estético deseado. Se han determinado dos tipos de retoques. Una primera modalidad consiste en el uso del agua de cal en las fronteras entre jornadas y utilización de empastes con "blanco de cal" en zonas de brillos y luces. Una segunda, opta por otros retoques con aglutinante de tipo proteico en paños y elementos secundarios o accesorios. En general, la paleta utilizada por Arbassia se ajusta a aquellos pigmentos tradicionalmente recomendados, ya que son estables a la acción alcalina de la cal: Negro (de carbono), Blanco (blanco de cal o carbonato 
cálcico y sulfato cálcico), Amarillo (ocre amarillo u óxido de hierro hidratado), Rojo (tierra roja u óxido de hierro), Azul (esmalte o silicato de potasio y óxido de cobalto) y Verde (tierra verde o silicato de aluminio, potasio, magnesio y hierro). Llama la atención el empleo de azurita mineral. Es un carbonato básico de cobre que era preparado para pintar simplemente seleccionando muestras de mineral de buen color y moliéndolo con agua o lejía, sin refinarlo demasiado, para que no empalidezca al reducirse su poder cubriente. Su color puede variar considerablemente, pues va de una azul intenso, levemente verdoso, a un azul pálido con un pronunciado matiz verde. La curiosidad de su empleo y, más concretamente, de su buen estado de conservación, es que era uno de los pigmentos tradicionalmente rechazados para su utilización en la técnica al fresco, puesto que se altera profundamente ante el medio alcalino propio de la pintura mural.

En cuanto a los recursos pictóricos de los que el autor hace gala a fin de conseguir un intenso plasticismo y resolverlo en una composición de carácter ilustre y culto, cabe señalar la utilización de pinceladas precisas, sólidas y largas, muy valientes por la combinación de tonalidades y por resolver luces y tonos intermedios haciendo partícipe a la capa de preparación en esta tarea. De este modo, cabezas, pies y manos especialmente, denotan la habilidad y espontaneidad de quien puede conseguir efectos expresivos y definición de los volúmenes con trazos perfectamente dispuestos y seguros. Con total seguridad no puede hacerse la misma afirmación acerca de las proporciones generales en las figuras o su resolución cromática. Esta misma irregularidad en el trabajo podemos encontrarla en las soluciones utilizadas en los paños: mientras algunas túnicas y mantos se resuelven con tonos intensos cuyas sombras en los plegados presentan igualmente colores violentos (amarillorojo, verde-rosa, etc) resultando un conjunto de gran viveza, otras son prácticamente monocromas, sin juego de volúmenes y denotando, quizás, una ejecución poco estudiada. Por último, la capacidad de recursos pictóricos que el autor parece dominar queda patente en la posibilidad de conseguir pinceladas difuminadas y efectos de sfumato (Ángel de la Oración en el Huerto) junto a trazos precisos y minuciosos (piezas de vajilla y trozos de pan sobre la mesa de La Cena). En cualquier caso, parece que Vasari se refiriera a él cuando afirma:

También, y es lo principal, se requiere una mano hábil, resuelta y veloz, y. un juicio seguro y certero, porque además de lo dicho, mientras se trabaja es imposible juzgar los colores, ya que cambian una vez que la cal se seca. Por eso, repetimos, en los trabajos al fresco más que por el dibujo mismo, el artista debe guiarse por una enorme práctica, puesto que es sumamente dificil llevar a cabo la obra y dejarla terminada a la perfección ${ }^{53}$.

53 VASARI, G.: op. cit., págs. 114-115 (cap. XIX) 
Por su lado, la presencia de las pinturas subyacentes bajo las capas de cal, aparecidas ante la necesidad de realizar las limpiezas pertinentes de los paramentos y elementos arquitectónicos del conjunto, hacía imprescindible prolongar el estudio de los motivos ornamentales en la línea ya iniciada con los frescos a la vista, es decir, su identificación material mediante análisis físico-químicos, la técnica de ejecución, su actual estado de conservación y aproximación a una autoría o escuela. De todo ello se dedujo el paralelismo existente entre ambos, a saber, correctísima técnica al buon fresco, dibujo preparatorio inciso, empleo de pigmentos y morteros habituales en pintura mural y un nivel adecuado de estabilidad y buena conservación (exceptuando las decoraciones de los arcos bajo los frescos, donde el empleo de una técnica pictórica a la cal y un mortero de peor calidad había producido importantes problemas de pulverulencias y disgregaciones). Para obtener una aproximación al aspecto general que la capilla podría tener en el s. XVI se llevó a cabo la apertura de unas catas localizadas en cada una de las secciones arquitectónicas, mostrando la magnífica ejecución de las figuras de los ángeles, la riqueza cromática de los quizás excesivamente abigarrados grupos vegetales, los efectos de trampantojo maromeado en las bases de las pilastras, los remates de los frescos y elementos arquitectónicos fingidos, etc.

\section{El proceso de restauración de las pinturas}

Metodología de trabajo. Para la realización de los trabajos pertinentes, la premisa ineludible fue el diseño de las fases de estudio según los esquemas de organización establecidos a priori y que se basan en un análisis visual, científico y documental, imprescindibles para la obtención de los datos necesarios y la elaboración de conclusiones de amplio espectro. La conservación y restauración de bienes culturales implica, hoy día, un conocimiento profundo del objeto a tratar y de las circunstancias que lo envuelven a fin de no modificar innecesariamente su contexto.

1. Investigación histórica y análisis documental. Conocimiento desde el plano teórico-documental de los aspectos históricos y artísticos de la obra en su conjunto y por elementos individuales. Se obtienen estudios compositivos, iconográficos, estilísticos comparativos y de autoría que profundizan en el conocimiento de la obra sobre la cual intervenir.

2. Identificación de técnicas y materiales. Estudio de las técnicas tradicionales de ejecución, en base a las fuentes escritas originales, sobre la pintura al fresco, escultura policromada, acabados en pan de oro, etc. a fin de profundizar en las manufacturas y los materiales empleados en este conjunto, estudiando los procesos de evolución temporal y las posibles actuaciones de restauración anteriores. 
3. Estudio gráfico-óptico. Identificación gráfica de los aspectos formales, compositivos y estructurales del conjunto como medio imprescindible para la localización de deterioros y sus causas. Para ello se realiza la siguiente documentación:

3.1.- Fotografías bajo luz normal, de conjunto y detalles, a fin de plasmar el actual estado de conservación. Ofrecen datos de resolución formal y estructural.

3.2.- Fotografías con luz rasante. Imprescindibles para situar las zonas de abolsados, craqueladuras, ampollas, desprendimientos, falta de adhesividad entre las capas, resaltes y empastes de ejecución, etc.

3.3.- Macrofotografías. Definen con mayor exactitud los daños de origen mecánico, físico-químico y biológico, así como detalles de la ejecución pictórica, añadidos, etc.

3.4.- Fotografías bajo luz UV. Ofrecen un mapa de reintegraciones añadidas en época posterior a su ejecución, el estado de la capa de protección, presencia de microfisuras, etc.

3.5.- Documentación gráfica. La realización de dibujos de la capa pictórica permite ofrecer todas las características y circunstancias especiales de la obra. Mediante transparencias se señalan las pérdidas o lagunas, estucos y reintegraciones. Del mismo modo se sitúan las zonas de toma de muestras para su análisis químicos. Los esquemas fueron realizados por Francisco Zambrana Salido.

4. Estudio fisico-químico. Analítica de las muestras extraídas de las capas de preparación y pictórica tanto de los frescos como de una de las esculturas, ornamentación en pan de oro y de la pintura subyacente en uno de los pilares laterales. Se realiza mediante Microscopía Óptica, Microscopía Electrónica de Barrido combinada con Espectrometría de rayos $\mathrm{X}$, ensayos microquímicos y Espectrometría Infrarroja por Transformada de Fourier. De esta forma se obtiene el reconocimiento y cuantificación de los materiales constituyentes, inorgánicos y orgánicos, de las diferentes capas o estratos (soportes, capas de preparación, pigmentos, aglutinantes, barnices...) estudiando su comportamiento ante la actuación de agentes externos: contaminación, cambios de temperatura y humedad, iluminación artificial,... y sus procesos de envejecimiento. Las investigaciones fueron realizadas por técnicos especialistas del Departamento de Conservación y Restauración de la Facultad de Bellas Artes de la Universidad Autónoma de Valencia.

5.- Investigación biológica. Estudio de la contaminación biológica (mohos y levaduras), mediante la toma de muestras en puntos que presentan signos de actividad biológica e identificación de aquellos mediante su estudio en laboratorio de microbiología. De este modo se puede obtener un estudio de alternativas de desinfección. Para la realización de este apartado se ha contado con la colaboración del Departamento de Microbiología de la Facultad de Ciencias de la Universidad de Málaga. 
La capilla mayor de la Catedral de Málaga: palimpsesto y escenografía pintada

\section{Estado de conservación}

1. Soporte mural. No se ha podido realizar un estudio exhaustivo del actual estado de conservación del material constituyente de este estrato, al no existir lagunas de suficiente tamaño como para permitir al menos una toma de muestra del mismo $\mathrm{y}$, de este modo conocer con mayor profundidad posibles alteraciones intrínsecas que puedan traducirse en daños paralelos sobre las capas superpuestas. Pero, probablemente, ciertas fisuras presentes se deban al estado tensional del conjunto y su correspondiente deformación estructural. Como ya se ha indicado, es de gran importancia el hecho de que se tratan de pinturas exentas de muros y elevadas sobre arcos, no sufriendo, por tanto, de las nefastas influencias de humedades por capilaridad, filtraciones o escorrentía, aunque sí por condensación de vapor de agua sobre su superficie. Elementos accidentales, como los terremotos, pueden haber favorecido la separación de las capas preparatorias del soporte mural, constituido por ladrillos y mortero con árido grueso. También son causa de las lesiones y fracturas estructurales presentes en los arcos y entablamentos.

2. Revocos o capas de preparación. Los movimientos estructurales incontrolados, producidos por asentamientos diferenciales, dilatación y/o contracción de los materiales en función de los cambios termohigrométricos, y la deformación del conjunto derivada de su estado tensional, ha producido la fracturación de las capas de revoque, dañando física y estéticamente la obra. Su manifestación se concreta en fracturas y abolsamientos. Éstos se manifiestan como consecuencia de la descohesión entre los distintos estratos que forman la preparación de la pintura, tanto en capas internas como externas, creando bolsas de aire. Por otro lado se han observado: pérdidas de materia (huecos de tamaño medio y pequeño) en zonas determinadas, cierta pulverulencia y descohesión entre sus componentes, añadidos de morteros en zonas dañadas o antiguos huecos y pérdidas de tamaño importante, etc.

3. Capa pictórica. Las conclusiones aportadas por el estudio de las muestras químicas indican el aceptable buen estado de conservación de los colores, incluyendo la azurita, pigmento éste poco idóneo para ser utilizado en una técnica al fresco. Se pueden señalar, en cualquier caso, los siguientes daños puntuales:

3.1. De origen mecánico, provocados por arañazos, roces, golpes y las fracturas de las capas subyacentes, que se traducen en la policromía con las consiguientes pérdidas.

3.2. Lagunas de policromía que en ocasiones suelen concretarse en zonas de color determinado, lo que implica problemas específicos del pigmento afectado.

3.3. Lagunas puntuales en bordes de fisuras y fracturas, con pulverulencia de las diferentes capas constituyentes.

3.4. Depósitos de naturaleza orgánica (excrementos, huevos de insectos...)

3.5. Fuertes acumulaciones de polvo y suciedad superficial.

3.6. Depósitos de hollín, humos. 
3.7. Sin confundirlos con las giornatas de ejecución, se aprecian especialmente en dos de los paneles unas craqueladuras sutiles, derivadas probablemente de la rápida desecacióndel mortero o de las aplicaciones de temple graso o pinceladas a secco.

3.8. La presencia de las sales solubles se circunscribe a lagunas aéreas de la superficie pictórica, donde ha provocado levantamientos puntuales, pulverización del pigmento, separación de las capas de color y cristalizaciones superficiales en forma de florescencias y blanqueamientos. Tales fenómenos pueden imputarse a las intervenciones anteriores de consolidación con materiales no idóneos, a antiguas limpiezas a base de álcalis cáusticos o a la tipología del propio soporte murario.

3.9. Regueros de suciedad, donde se han reconocido compuestos de naturaleza orgánica, principalmente parafina y trazas de sustancias de tipo proteica. Esto confirma que se trata de ceras.

3.10. Exfoliaciones o levantamientos de láminas de color de dimensiones variadas. Se localizan especialmente en ciertos tonos determinados como la tierra verde o tierraamarilla y pueden tener su origen en el hecho de ser pigmentos más "grasos", es decir, con un cierto porcentaje de arcilla. Por la capacidad higroscópica de ésta se producen variaciones de volumen que crean fracturas separándose de la capa pictórica cristalina de la superficie y del soporte rígido murario. También pueden encontrarse en pinceladas con blanco de cal, más corpóreas en comparación con el intonaco liso.

3.11.- Pulverulencias localizadas muy puntualmente. Se trata de roturas micrométricas de la capa pictórica que, en la práctica, se reduce a polvo y es difícilmente recuperable. Normalmente se asocia a pigmentos poco aglutinados.

3.12.- Repintes. Pueden clasificarse en dos tipos: Realizados al óleo (se ubican en zonas de pérdidas de policromía y daños diversos del soporte. Normalmente no respetan las lagunas, cubriendo ampliamente el original. En la actualidad presentan una tonalidadoscura, de color tergiversado) y Retoques de color con, probablemente, técnica acuosa (dado el tono inferior al original y la transparencia. Suelen encontrarse intentando disimular los tonos claros del intonaco a la vista).

\section{Causas de alteración.}

Para el estudio del estado de conservación de las pinturas, los daños y deterioros se han clasificado atendiendo a su origen en tres grandes grupos:

1. Estructurales: los que tienen su origen en los movimientos estructurales del edificio. Se concretan en la superficie pictórica en forma de grietas y fisuras, abolsamientos y desprendimientos. Los paneles y zonas adyacentes presentan un cuadro fisurativo completo, con presencia de grietas direccionales y en mapa, así como un significativo porcentaje de abolsamientos entre revoques, que hacen peligrar 
La capilla mayor de la Catedral de Málaga: palimpsesto y escenografía pintada

la integridad de ciertas partes del conjunto pictórico. Estos abolsamientos normalmente coinciden con zonas de fisuras profundas.

2. Biológicas: este tipo de deterioros se distribuyen en pequeñas aunque numerosas áreas localizadas de la superficie pictórica. Se han encontrado depósitos de materia orgánica (agregaciones de huevos), pequeños orificios, manchas y micropérdidas de pintura.

3.Químico-físicas: se han observado degradaciones producidas por alteraciones químicas de los propios materiales constitutivos de la obra, sobre todo en retoques a seco, así como la degradación de antiguos repintes. El ennegrecimiento de las pinturas por acumulación de suciedad es una de las alteraciones más importantes en las pinturas, confiriéndole un aspecto falseado y monótono, con pobreza de valores cromáticos. Ello tiene su origen en la contaminación por visitantes y por la combustión de velas. En muy escasa medida son debidas a la contaminación ambiental externa.

\section{Tratamiento efectuado.}

1.- Documentación previa. Toma de documentación gráfica y fotográfica. Se realizan fotografías de conjunto y detalle bajo luz normal, rasante, ultravioleta y macrofotografías a fin de obtener la mayor información posible de las obras. Entre otros datos salen a la luz la ubicación exacta de los repintes añadidos en intervenciones anteriores y detalles de técnica de ejecución, como son el empaste producido por la aplicación de pinceladas con aglutinante a base de agua de cal, la superposición de capas pictóricas, el punteado con spolvero a base de negro humo para ejecutar el dibujo preparatorio, las líneas incisas que definen los rasgos generales de la composición, las divisiones de giornatas y la aplicación de pinceladas a seco para disimularlas, así como las diferencias tonales entre dos zonas adyacentes pero realizadas en jornadas distintas. Del mismo modo, se realizan dibujos y planos de cada panel pictórico a fin de ubicar los daños que presentan, tales como abolsados, diferencias de rasante, grietas, fisuras o fracturas, lagunas, etc.

2.- Documentación científica

2.1. Estudio físico-químico. A fin de obtener la mayor información posible de la composición estatigráfica de los paneles pintados, incluyendo la composición mineralógica de cada uno de los estratos, el grosor de las capas aplicadas, la mezcla de pigmentos elegida para la obtención del tono deseado, el tamaño del grano y tipo de molienda, la estabilidad de los materiales, así como las características de los depósitos de suciedad añadidos, se extrajeron muestras de todos los paneles pintados (entre 3 y 4 por unidad) procurando diversificarlos para obtener conclusiones de amplio espectro. La elección de las muestras iba dirigida a identificar los diferentes pigmentos utilizados, las zonas a mezzo fresco o con pinceladas a seco, los repintes, los aglutinantes, etc. 
2.2. Análisis microbiológico. A fin de obtener la mayor cantidad posible de información en cuanto al actual estado de conservación del conjunto de la cabecera, se planteó la necesidad de la toma de muestras de contaminantes biológicos en la superficie de las pinturas. Cabe decir que cuantitativa y cualitativamente hablando, en las zonas analizadas la contaminación fúngica no es importante, identificándose como Penicillium y Aspergillus, ambos de la clase Ascomicetos. Ambos provocan manchas micelares de diferentes colores (el Penicillum de color verde), degradación y acidificación.

3.- Consolidación de los estratos. Un daño frecuente en la pintura mural es la disgregación de los morteros con la consiguiente pérdida del pigmento y la descohesión de los estratos. La causa principal de este fenómeno deriva sobre todo de factores termohigrométricos, la presencia de compuestos salinos y los movimientos por asentamiento de la estructura muraria, como ya se ha indicado anteriormente. Por tanto, teniendo en cuenta los tipos de daños a paliar, las causas que los han provocado, la circunstancia de ser paramentos que se conservan en un interior, la ausencia de humedades por capilaridad o filtración (sólo condensación), el tipo de iluminación combinada natural-artificial y la dificultad de un mantenimiento o renovación dada su ubicación, las intervenciones de consolidación superficial y en profundidad y la renovación de la adhesividad entre los diferentes estratos constituyentes se ha llevado a cabo de forma puntual y específica según la zona a tratar.

4.- Limpieza. Consiste en levantar de la superficie todo cuanto es extraño a la naturaleza de la obra (tanto la suciedad depositada como los repintes), que desnaturaliza y ofusca los tonos originales e impide la apreciación de detalles y puede resultarle nocivo; constituye, por tanto, un momento determinante del proceso conservador. No se trata sólo de eliminar sino de neutralizar, sobre todo en el caso de las sulfataciones, las acciones química y físicamente dañinas a la obra y supone la posibilidad de recuperar la imagen en su estado original, sin obviar la importancia y el carácter que la pátina (entendida ésta como el envejecimiento natural de los materiales y documento imprescindible para la comprensión del paso del tiempo) ofrece al aspecto final del conjunto. Como precaución ineludible, es fundamental el aporte científico para valorar los mecanismos de acción de los productos de limpieza escogidos, impidiendo o limitando, de este modo, la posibilidad de efectos negativos.

5.- Estucado. Su papel es importante, ya que impide que los materiales de alteración se depositen en las cavidades, evita las escamaciones y restituye la unidad de lectura de la obra.

6.- Reintegración. La reintegración pictórica tiene como objetivo restituir la lectura unitaria y homogénea de una obra de arte alterada, matérica y cromáticamente, con lagunas y abrasiones provocadas por las vicisitudes del tiempo. Esta intervención debe realizarse sin modificar el valor que el tiempo ha conferido a la pintura, es decir, la pátina y sin, naturalmente, crear una falsificación: cada operación de restauración 
debe tener como objetivo exclusivamente la conservación de la obra de arte, manteniendo inalterable la originalidad, el significado, el valor histórico-artístico y documental. Es por ello por lo que la reintegración debe ser siempre diferenciada y distinguible del original. Con la técnica del regatino se recubre la laguna con color aplicado mediante líneas verticales que se disponen ininterrumpidamente desde la zona alta a la baja de la laguna y mediante la combinación de colores adecuada a la tonalidad deseada. Como medio de reintegración se utiliza la acuarela o los lápices acuarelables, que no van a afectar a la estabilidad de los materiales, son muy reversibles y ofrecen un aspecto transparente y sutil.

7.- Protección final. Habitualmente se ha considerado la aplicación de una capa de protección (barniz, resinas sintéticas, goma-laca, ceras, etc.) sobre las obras de arte como un sistema válido e imprescindible para proteger la superficie. Sin embargo, en el caso de pintura mural deben considerarse otros aspectos importantes que se relacionan especialmente con la propia naturaleza de la obra, su ubicación parietal, la influencia de luces ambientales naturales (cambiantes) o artificiales, etc. Si a ello se le une el hecho que esta técnica conlleva en su propia naturaleza una sólida protección externa por efecto de la carbonatación de sus materiales constituyentes, puede obviarse la aplicación de otro elemento añadido o superpuesto. Es evidente que un muro está bajo la influencia de agentes de deterioro externos, de los cuales debe aislarse, pero en el caso que nos ocupa éstos se minimizan al encontrarse en un interior. Y las causas de alteración que pueden afectarle -humo, hollín, microorganismos, etc.- siempre tendrán unos procesos de limpieza y neutralización menos estresantes que la aplicación de productos químicos dirigidos a renovar las protecciones aplicadas, una vez producida su cristalización u oxidación. En función a estos razonamientos se ha seguido el criterio, comúnmente aceptado, de no aplicar una protección final. 
Juan Antonio Sánchez López / Estrella Arcos von Haartman

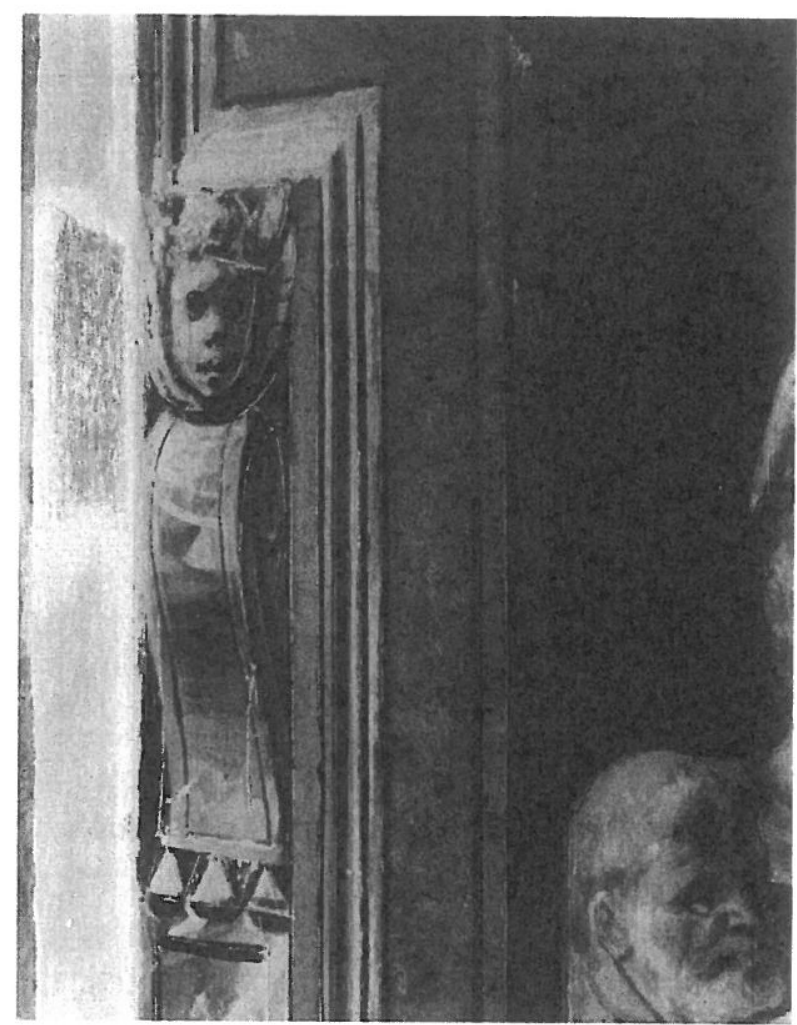

1.- Cesare Arbassia. Cabeza de querubín. Catedral de Málaga. Decoración pictórica del siglo XVI.

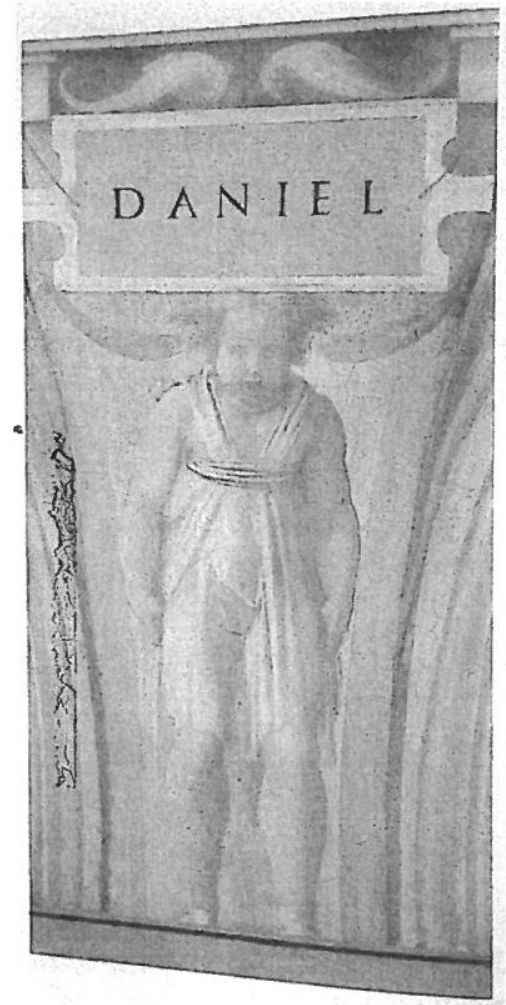

2.- Miguel Ángel. Putto portador de la placa del profeta Daniel. Capilla Sixtina. Vaticano.

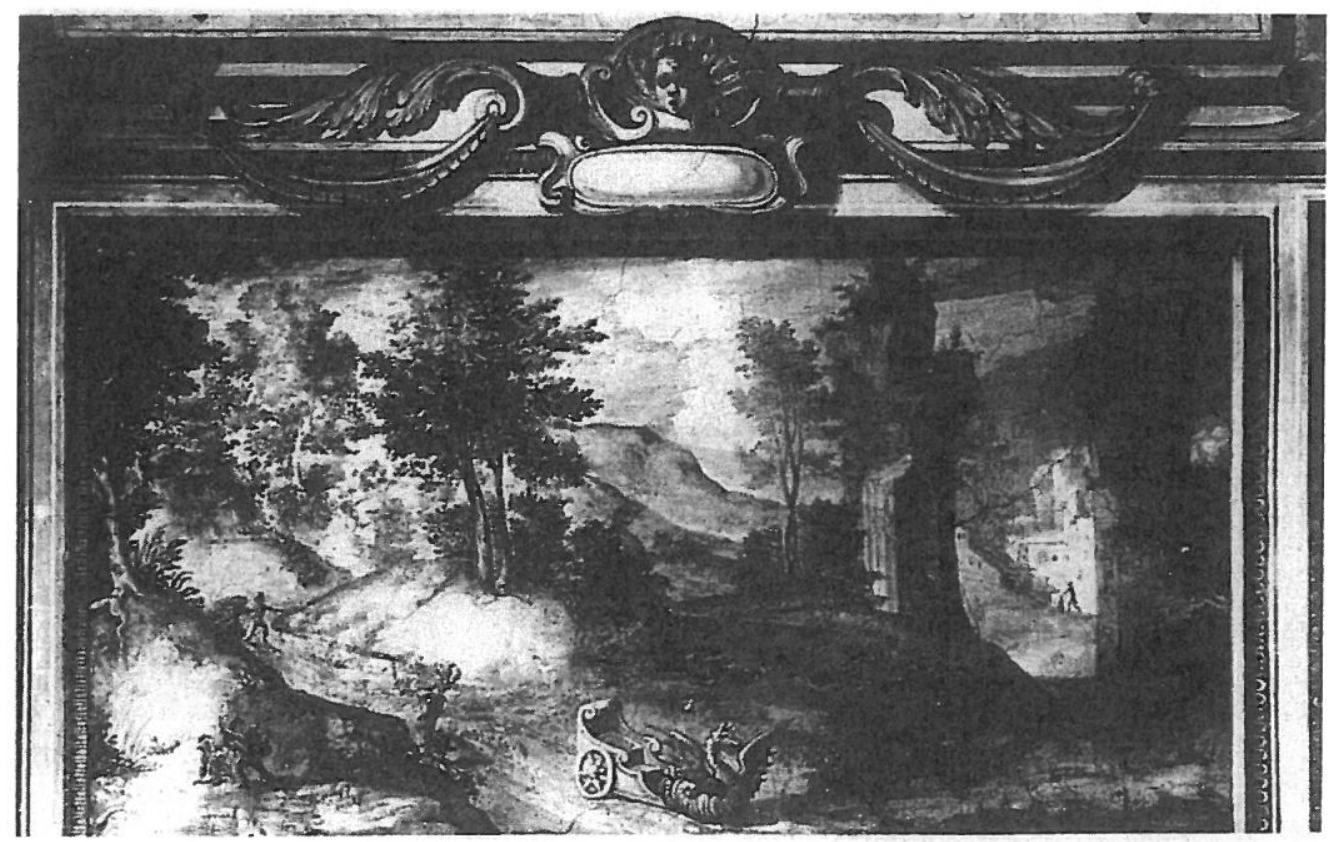

3.- Cesare Arbassia. Paisaje con marco fingido. Salas de Gregorio XIII. Vaticano. 
La capilla mayor de la Catedral de Málaga: palimpsesto y escenografía pintada
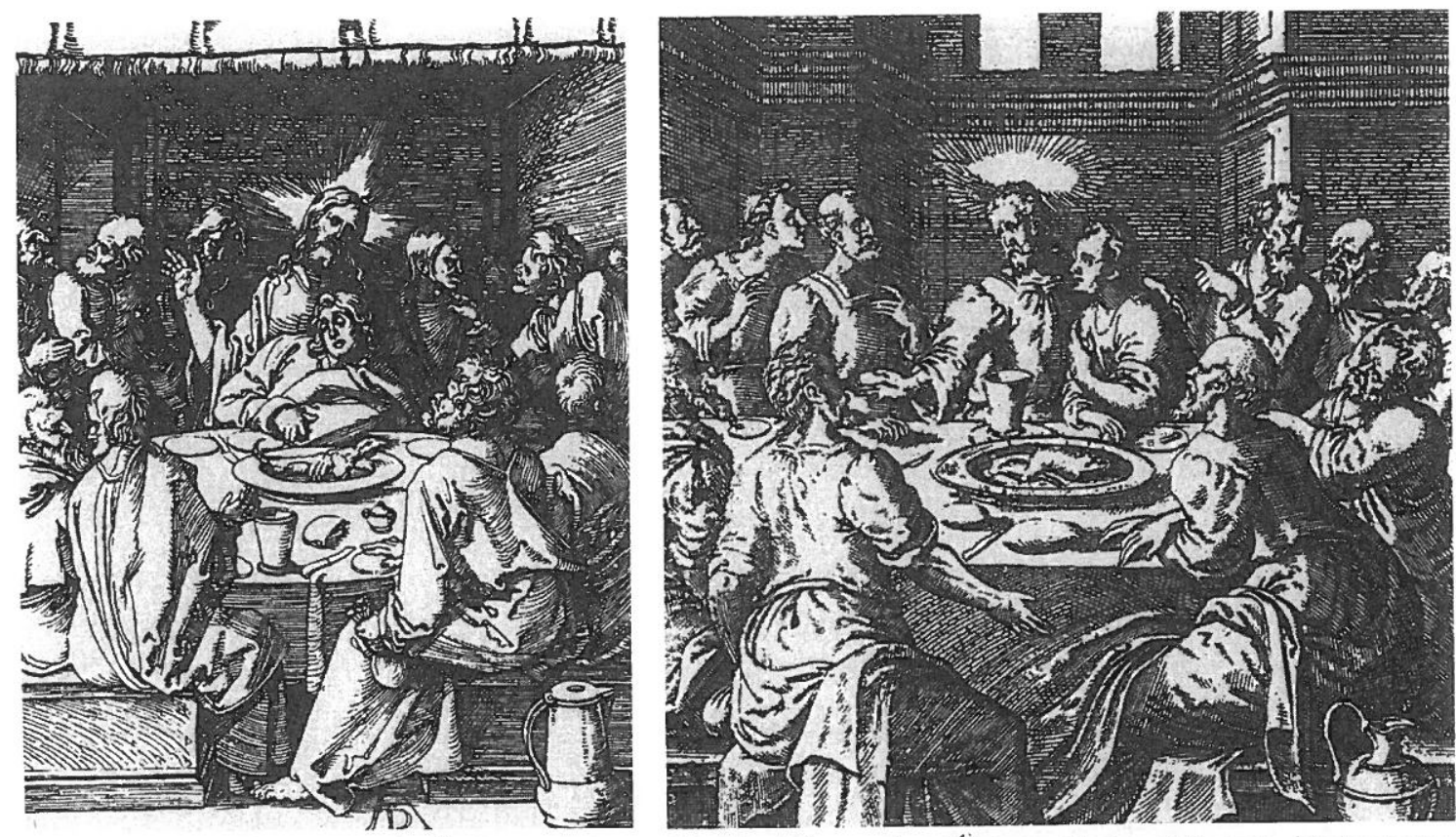

4.- Alberto Durero. La Última Cena. 5.- Anónimo. La Última Cena. Missale Romanum. Xilografía de la Pequeña Pasión. Amberes s. XVI.

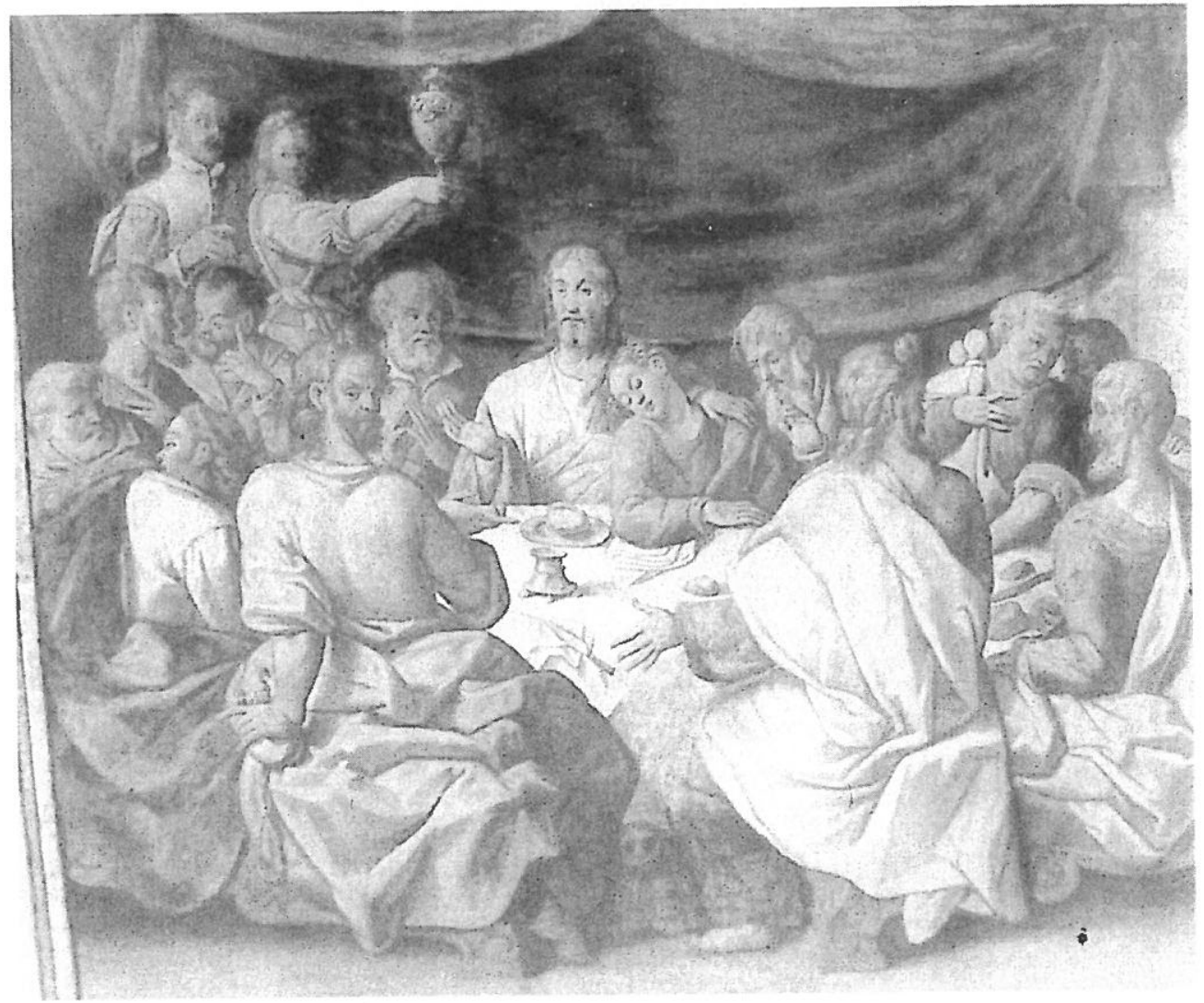

6.- Cesare Arbassia. La Última Cena. Catedral de Málaga. 
Juan Antonio Sánchez López / Estrella Arcos von Haartman

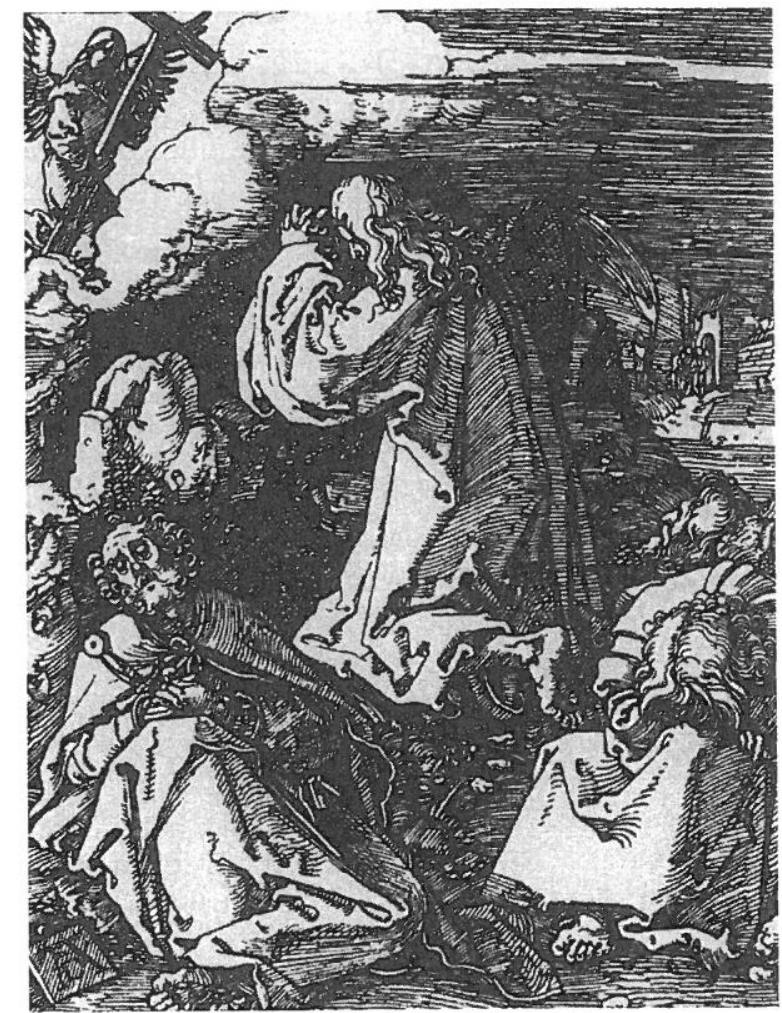

7.- Alberto Durero. La Oración en el Huerto. Xilografía de la Pequeña Pasión.

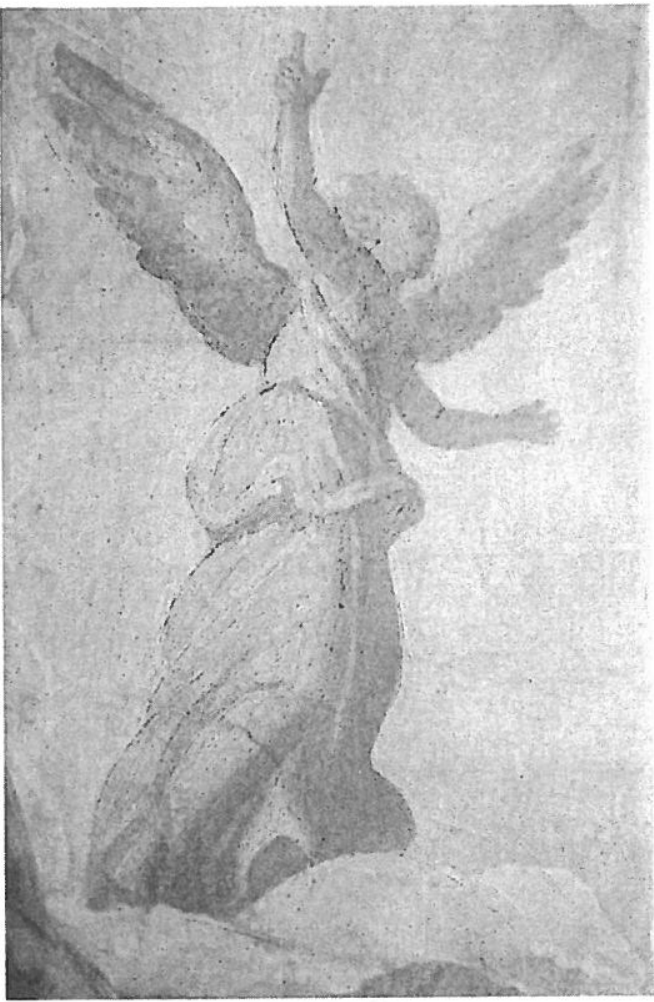

8.- Cesare Arbassia. Pormenor del ángel de la Oración en el Huerto.

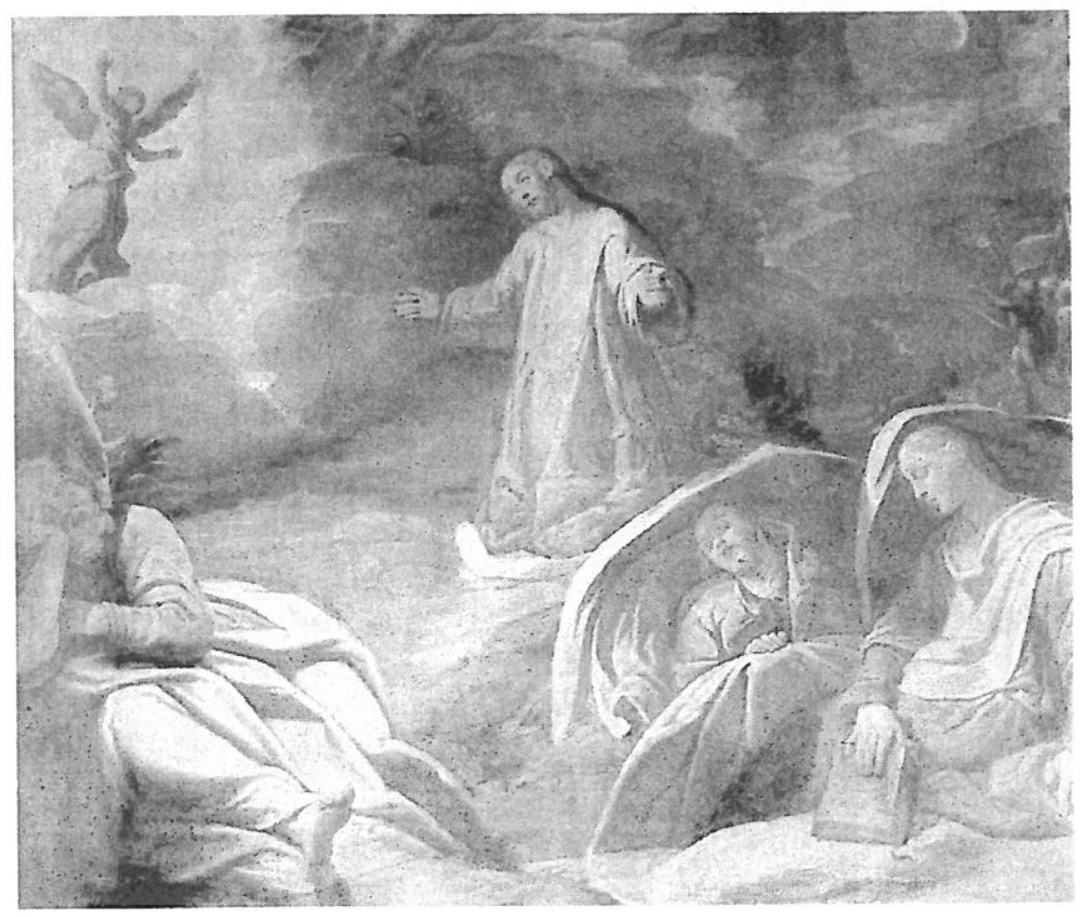

9.- Cesare Arbassia. La Oración en el Huerto. Catedral de Málaga. 
La capilla mayor de la Catedral de Málaga: palimpsesto y escenografía pintada

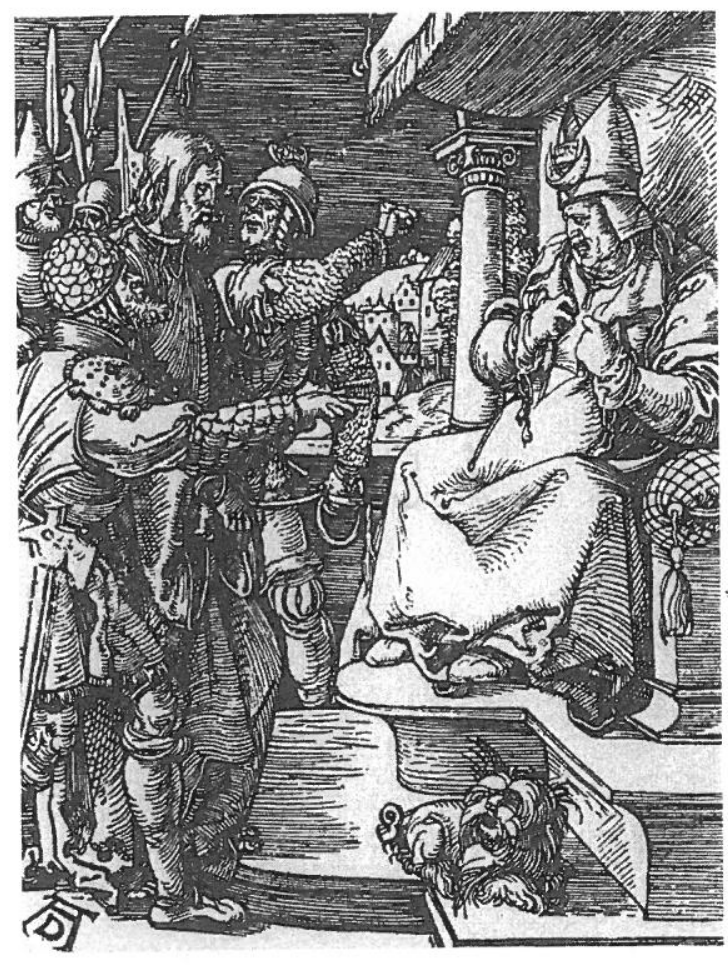

10.- Alberto Durero. Jesús ante Caifás. Xilografía de la Pequeña Pasión.

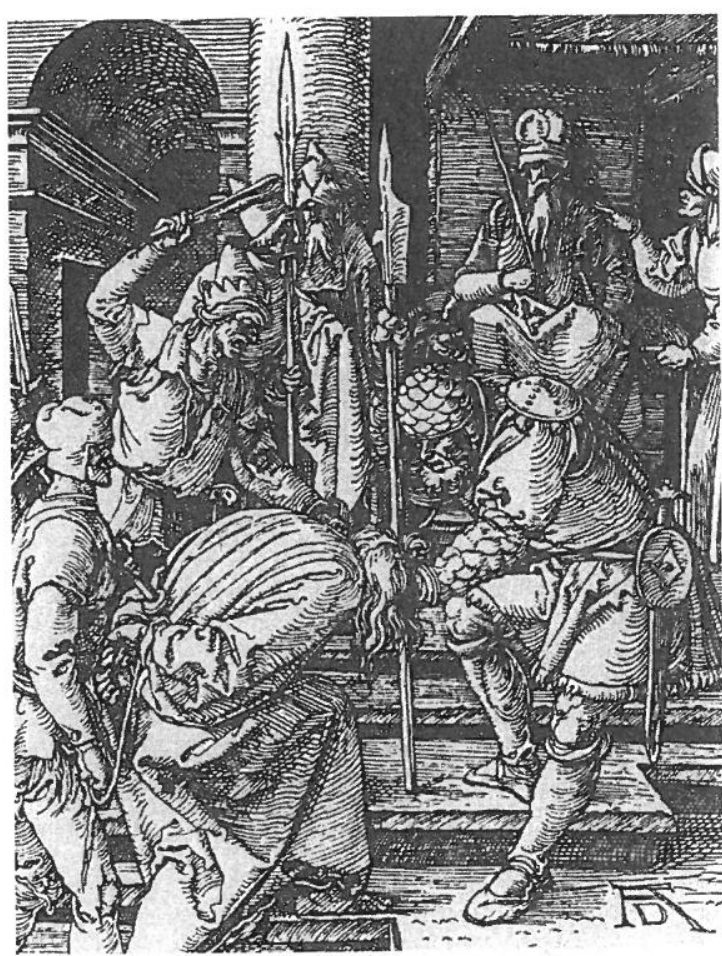

11.-Alberto Durero. Jesús ante Anás. Xilografía de la Pequeña Pasión.

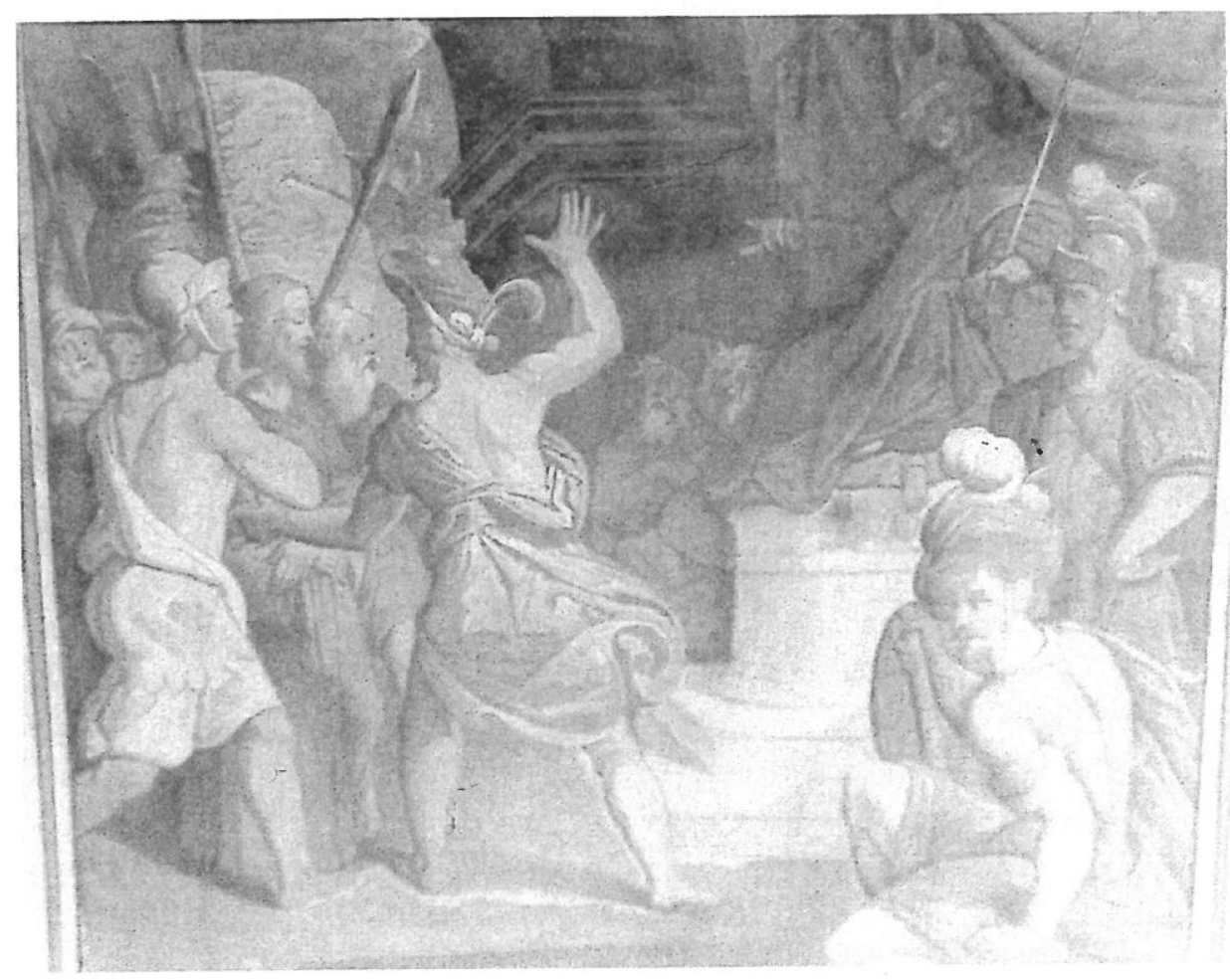

12.- Cesare Arbassia. Jesús ante Anás. Catedral de Málaga. 


\section{Juan Antonio Sánchez López / Estrella Arcos von Haartman}

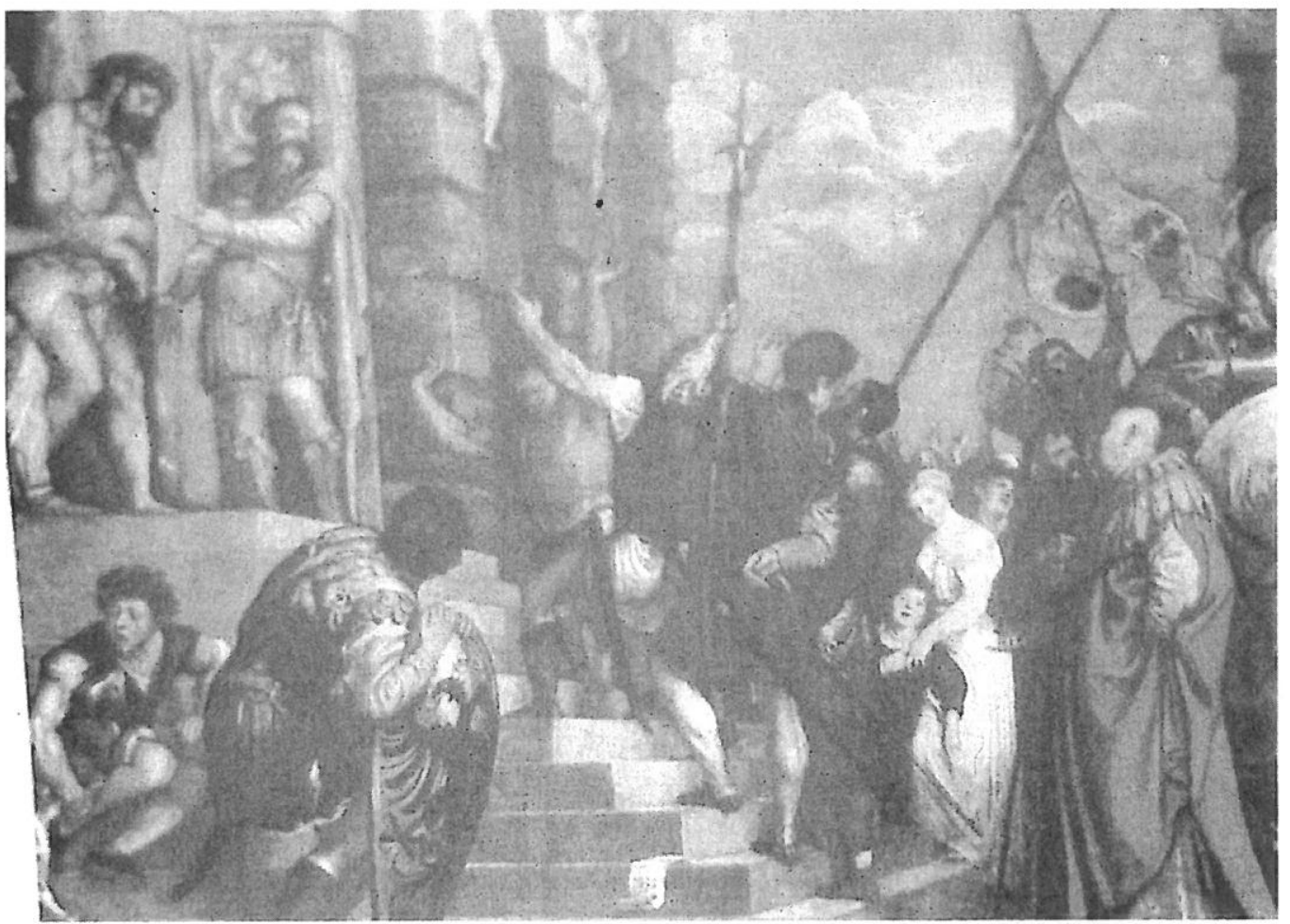

13.- Tiziano Vecellio. Ecce-Homo. Kuntshistorisches Museum. Viena.

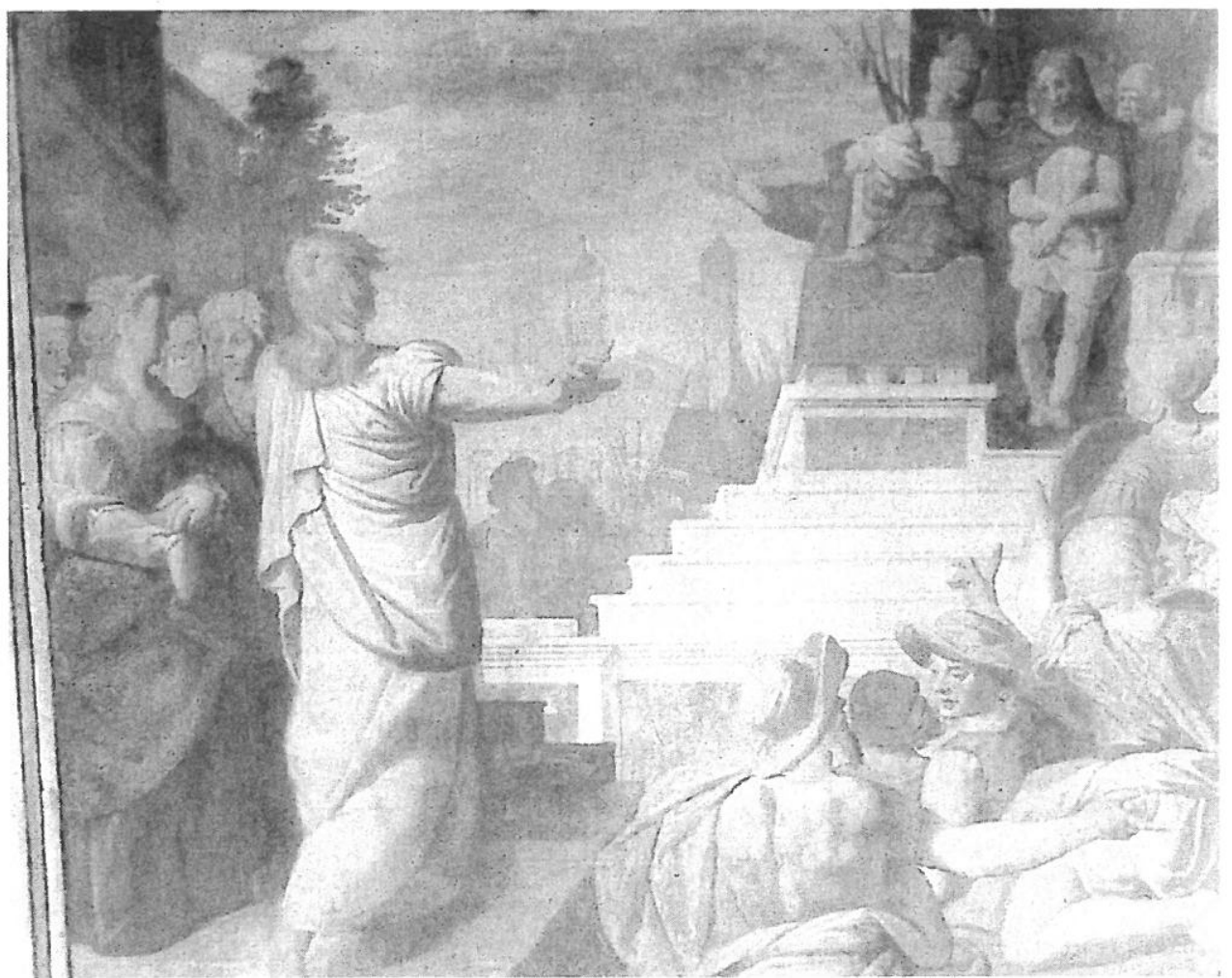

14.- Cesare Arbassia. Presentación de Jesús al pueblo por Pilatos. Catedral de Málaga. 
La capilla mayor de la Catedral de Málaga: palimpsesto y escenografía pintada

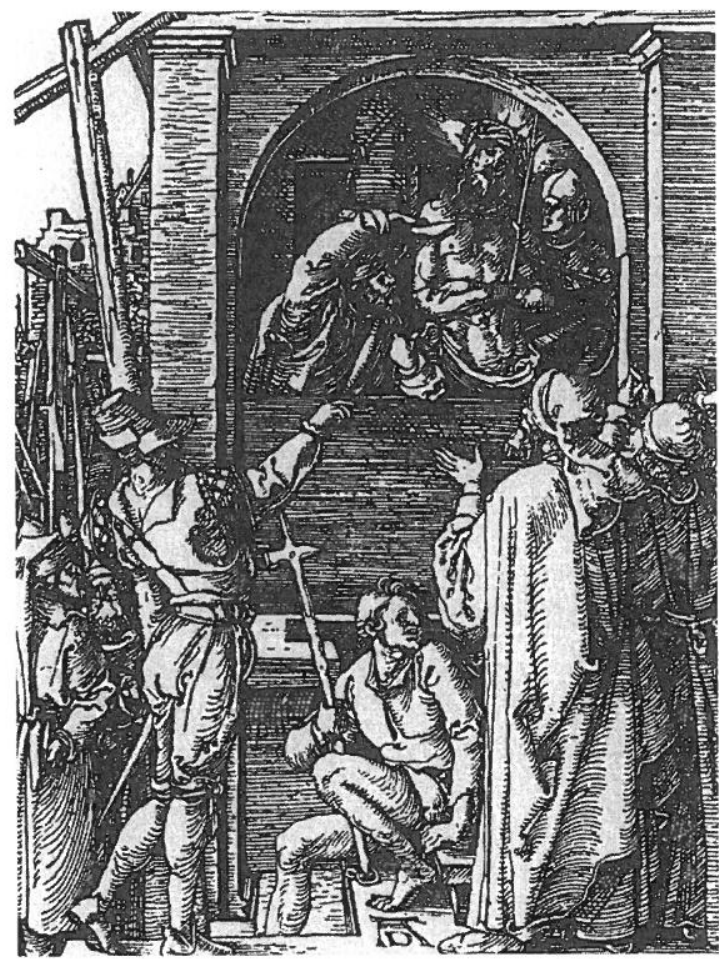

15.- Alberto Durero. Presentación de Jesús al pueblo por Pilatos. Xilografía de la Pequeña Pasión.

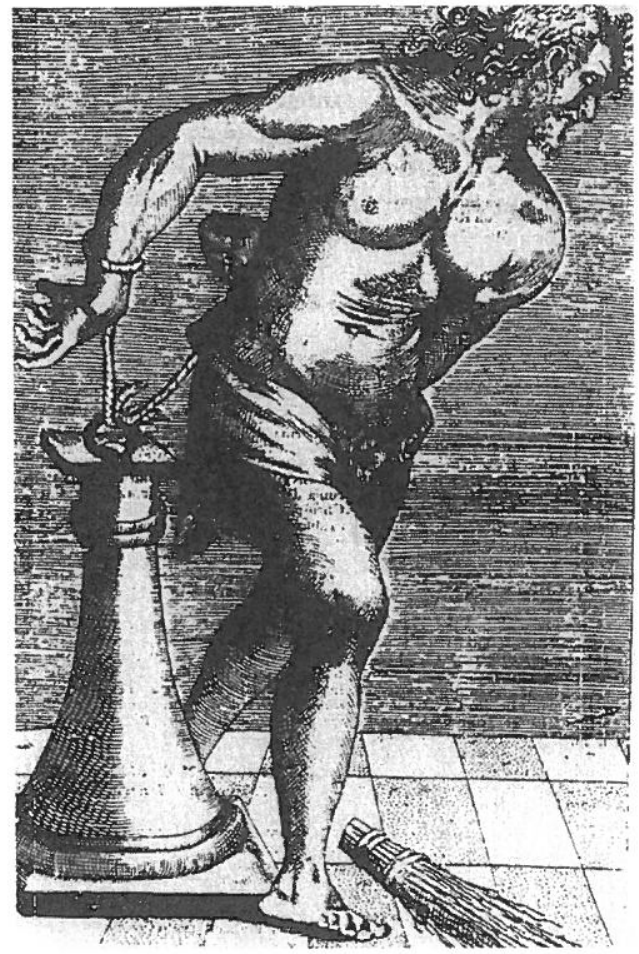

16.- Cristo azotado. Grabado inserto en la obra Iesu Christi Crucifixi Stigmata (1606) de Alphonso Paleotti y Daniele Mallonio.

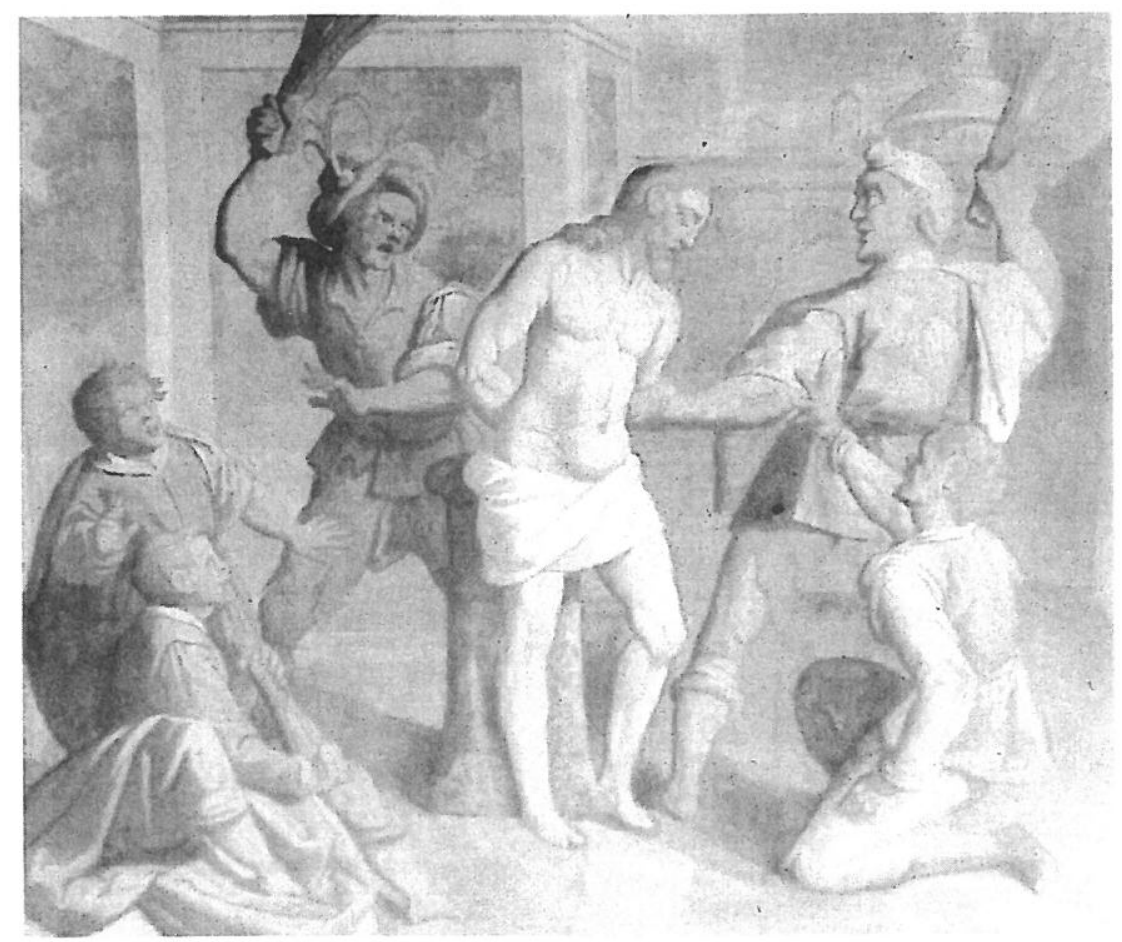

17.- Cesare Arbassia. La Flagelación. Catedral de Málaga. 
Juan Antonio Sánchez López / Estrella Arcos von Haartman

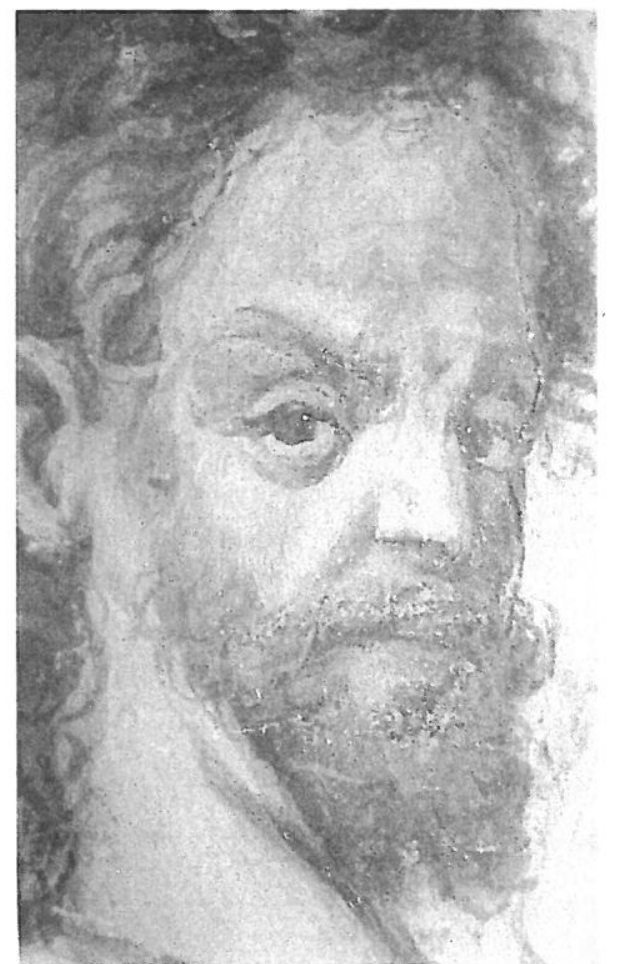

18.- Cesare Arbassia. Cabeza de Judas. Pormenor de la Última Cena.

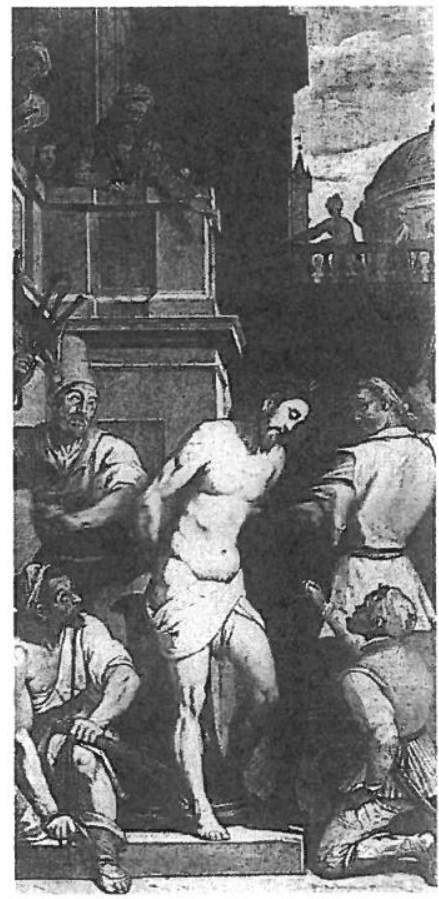

20.- Federico Zuccaro. La Flagelación. Monasterio de San Lorenzo. El Escorial. Compárese con la fig. 17.

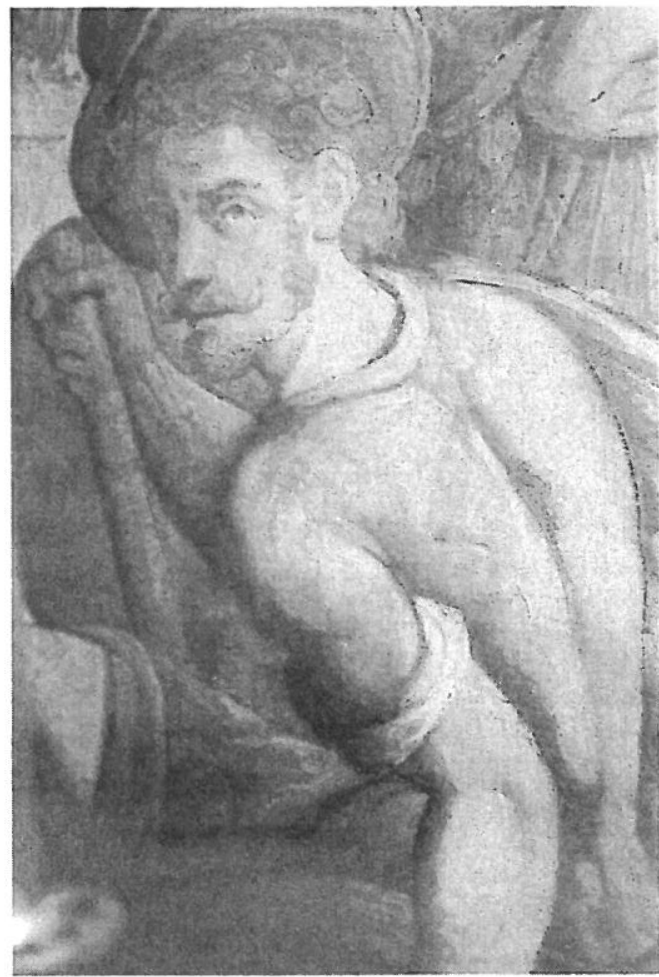

19.- Cesare Arbassia. Pormenor de Jesús ante Anás.

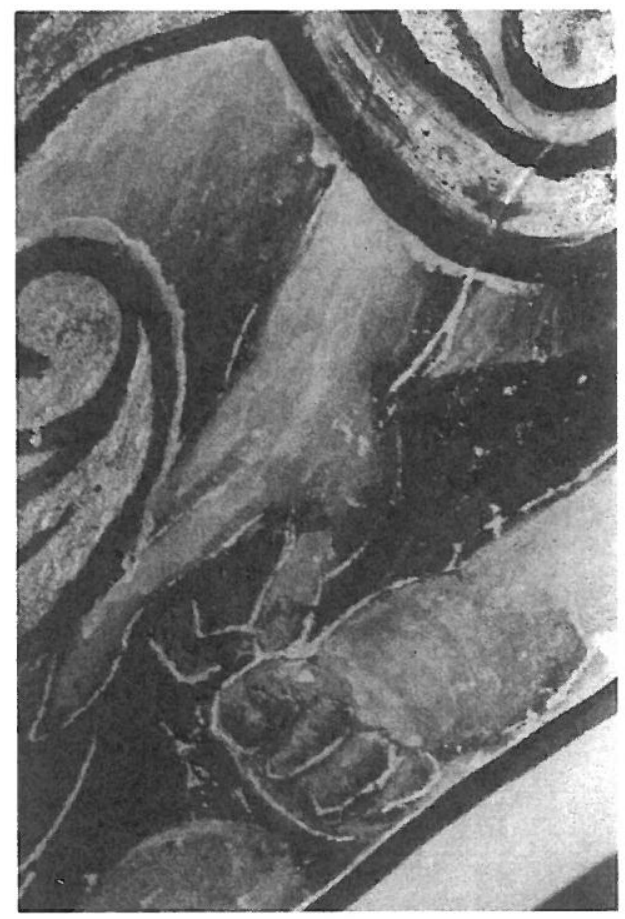

21.- Superposición de elementos de los siglos XVI y XVIII en las enjutas de los arcos, durante el proceso de restauración. 
La capilla mayor de la Catedral de Málaga: palimpsesto y escenografía pintada
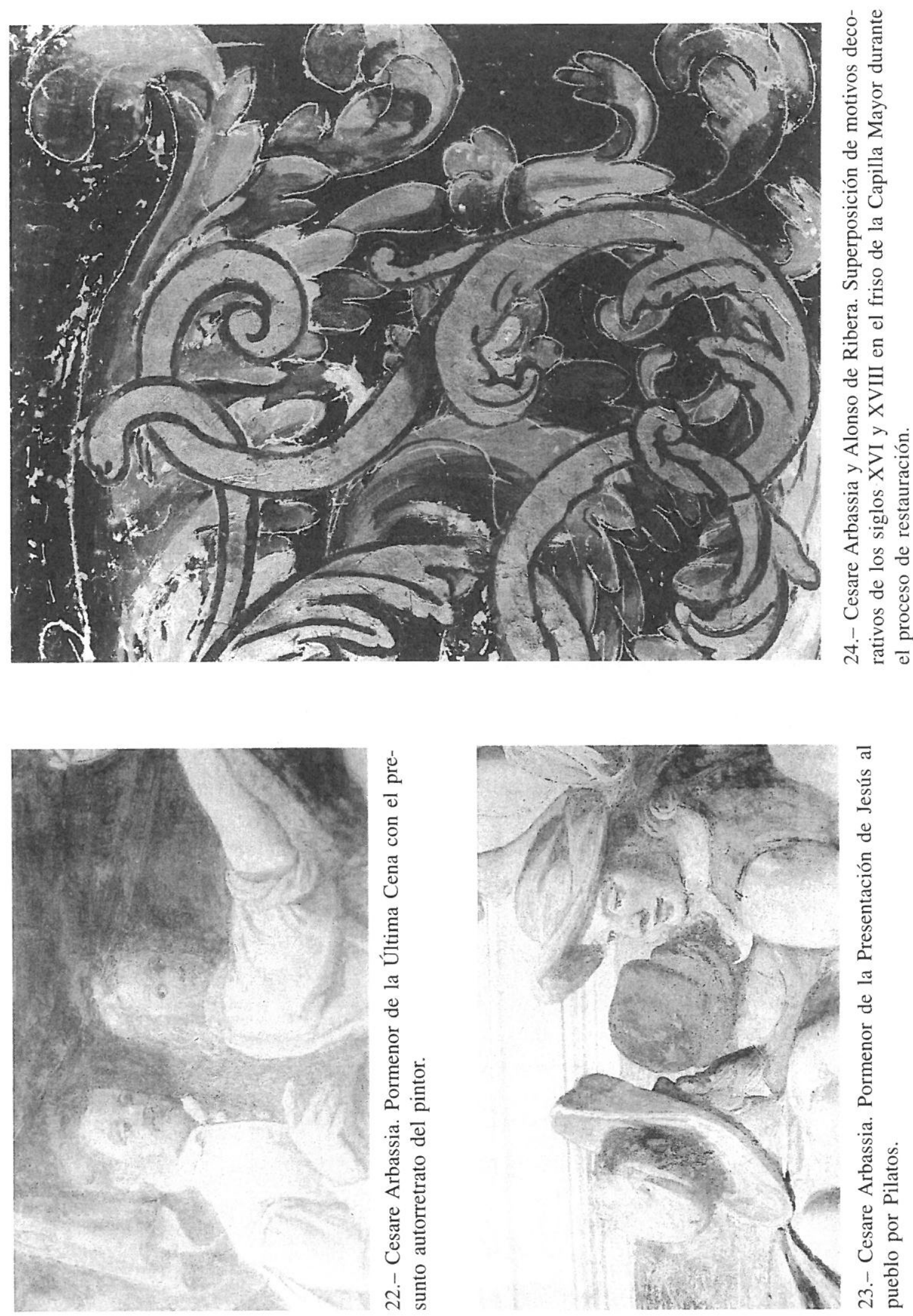
Juan Antonio Sánchez López / Estrella Arcos von Haartman

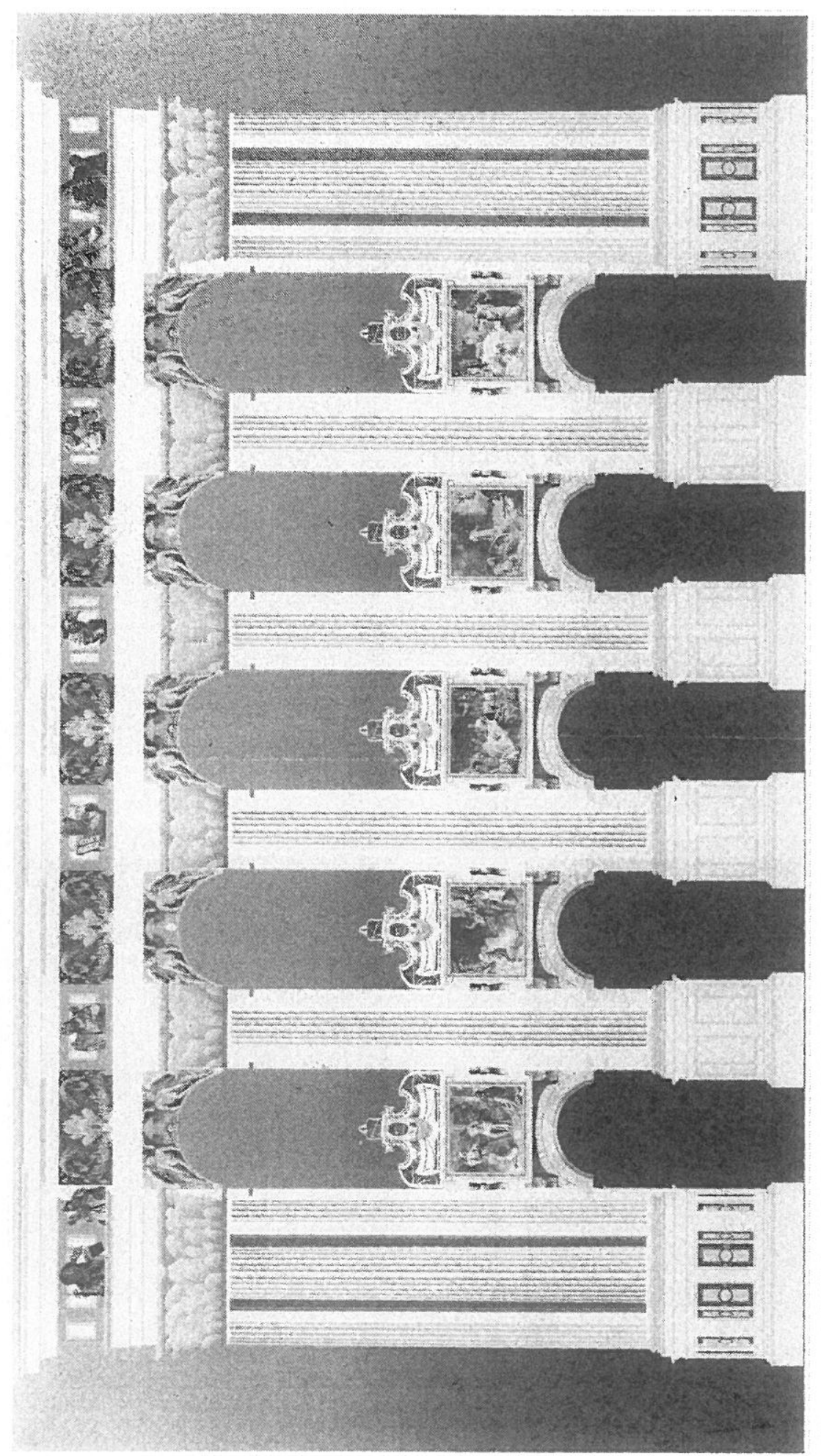

25.- Reconstrucción del programa pictórico del siglo XVI de la Capilla Mayor de la Catedral de Málaga. 
La capilla mayor de la Catedral de Málaga: palimpsesto y escenografía pintada

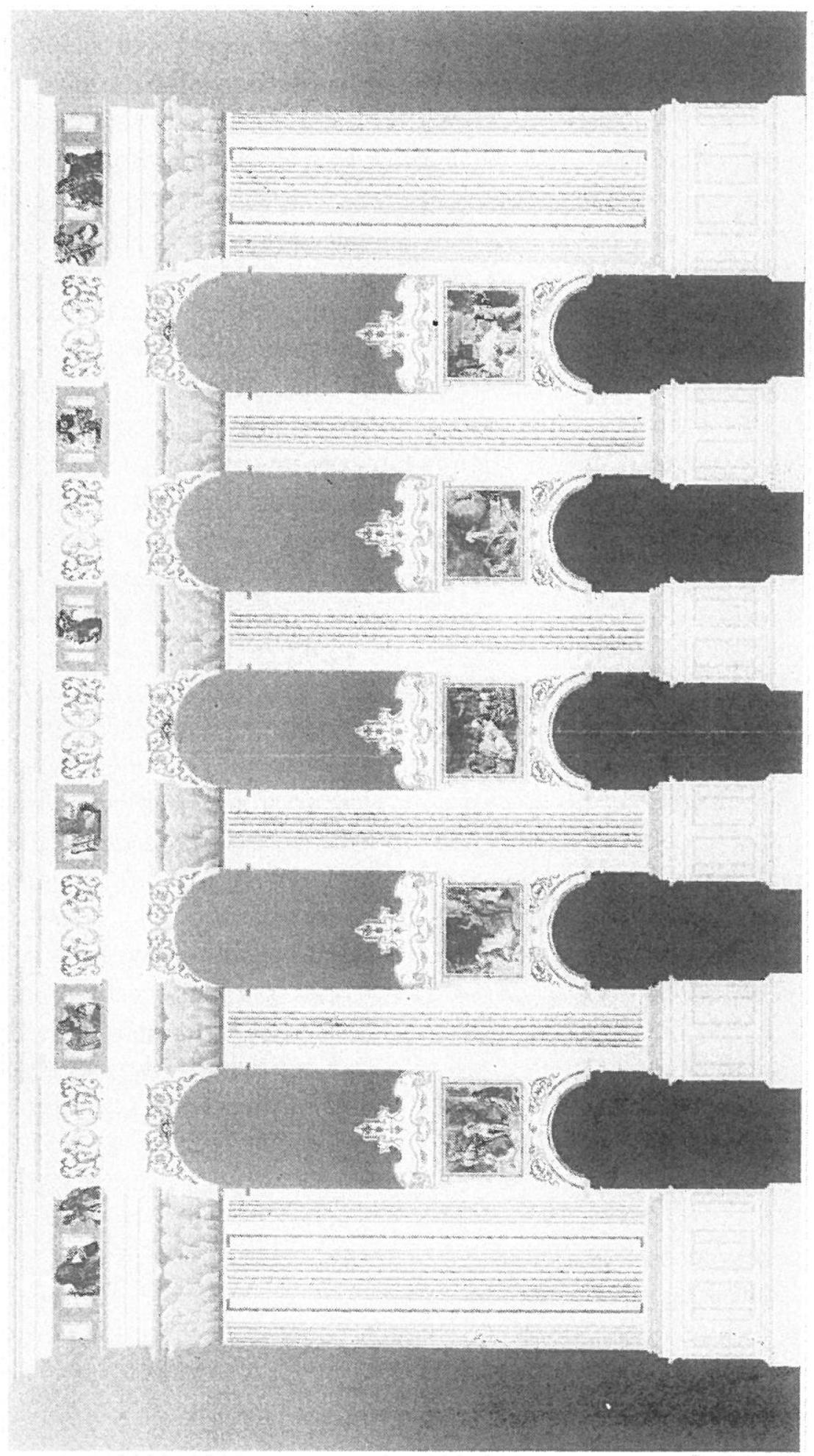

26.- Estado actual de la decoración pictórica de la Capilla Mayor de la Catedral de Málaga. 